\title{
Covalent silica-PEO-LiTFSI hybrid solid electrolytes via sol-gel for Li-ion battery
}

\section{applications}

\author{
J. F. Vélez ${ }^{\mathrm{a}, \mathrm{b}}$, M. Aparicio ${ }^{\mathrm{a}}, \mathrm{J}_{\text {. Mosa }} \mathrm{a}^{\mathrm{*}}$ \\ ${ }^{a}$ Instituto de Cerámica y Vidrio (CSIC), Campus de Cantoblanco 28049 Madrid (Spain) \\ ${ }^{b}$ Instituto de Ciencia y tecnología de polímeros (CSIC), Juan de la Cierva 3,28006 Madrid (Spain)

\section{Corresponding author} \\ jmosa@icv.csic.es (J. Mosa) \\ Instituto de Cerámica y Vidrio (CSIC), Campus de Cantoblanco 28049 Madrid (Spain)
}

\begin{abstract}
Organic/inorganic hybrid membranes based on (3-glycidoxypropyl) trimethoxysilane (GPTMS) and ethylene glycol diglycidyl ether (EGDE), have been prepared by sol-gel method and organic polymerization as solid electrolytes for Li-ion batteries. Lithium bis(trifluoromethane)sulfonamide (LiTFSI) was used as Li salt. FTIR and Raman spectroscopies were used to confirm the hybrid structure formation and the interactions between Li ions and hybrid network. An Arrhenius-like temperature dependence of ionic conductivity was observed for solid hybrid electrolyte membranes, suggesting that the diffusion of charge carriers was assisted by the segmental motions of the organic network. The Li-ion transfer number was determined and correlated with their ionic conductivities. Maximum ionic conductivities for the solid hybrid electrolyte membrane with LiTFSI and a $\left[\mathrm{Li}^{+}\right] /[\mathrm{O}]=0.10$ (class II hybrid) of $1.110^{-5} \mathrm{~S} / \mathrm{cm}$ was obtained at room temperature. A good value of electrochemical stability window $(7 \mathrm{~V})$ and an excellent high rate performance after 500 cycles make these hybrids materials a promising electrolyte candidate for all-solid-state lithium battery applications.
\end{abstract}

(C) 2016. This manuscript version is made available under the Elsevier user license http://www.elsevier.com/open-access/userlicense/1.0/ 
Keywords: all-solid-state; solid electrolyte; Li-ion battery; hybrid organic-inorganic, sol-gel.

\section{Introduction}

Rechargeable lithium-ion batteries (LIBs) are promising power sources that are currently used in many portable electronic devices and electric vehicles due to their high energy density, high operating voltage, low self-discharge, long cycle-life and low toxicity [1]. However new battery components must be developed for these applications in order to obtain high performance LIBs with better safety and low cost.

The electrolyte, as an important component of LIBs, plays a critical role in aspects of electrochemical performance and safety; however, traditional liquid electrolytes for commercial LIBs could cause safety concerns due to the leakage and explosive nature of volatile organic electrolytes, especially at high temperature $\left(>60^{\circ} \mathrm{C}\right)$ [2]. Recently solid polymer electrolytes are considered as the most promising candidates for high-temperature LIBs by virtue of enhanced safety and good thermal and dimensional stability [3]. Accordingly, there is an increasing tendency on the preparation and characterization of solid electrolytes that exhibit high ionic conductivity, high energy density, good cycleability, and safety [4]. As a result, several approaches have been developed in order to improve the ionic conductivity by increasing the amorphous content, such as addition of nanosized particles, copolymerization, dispersal of different fillers, synthesis of block copolymers or blends, branched/start branched and comb structures and also addition of different plasticizers [5-11]. Although these approaches present a lack of structural integrity and high conductivity that will be require for commercial applications. Another important strategy towards the synthesis of highly conductive solid electrolytes is the use of organic-inorganic hybrid electrolytes [1216]. The combination of inorganic and organic components in a suitable ratio using sol-gel 
and organic polymerization in the hybrid materials makes them structurally tunable for mixed with an organic precursor, generating nanostructured organic-inorganic hybrid structures with a high homogeneity in the nanometer scale and a complete amorphous structure, which is beneficial for ion conduction. The organic component allows adequate mechanical properties, meanwhile, the inorganic component is responsible for the enhancement of the thermal properties of the hybrid materials [17-25]. Recently, several authors published different strategies using hybrid materials. Saikia et col. [1,16, 20-24] used polyacrylonitrile (PAN) that provide a stable three- dimensional framework, which enhanced mechanical properties of the comb-like hybrid materials. On the other hand, J. Zhang and coworkers describe start-shaped hybrid materials based on oligomeric silsesquioxane (POSS), containing inner inorganic silicon oxygen core that facilitate lithium ion conduction [26]. X. Zhang's group using a combination of sol-gel technique and electrospinning to prepare hybrid materials based on PASN with high thermal stability and enhanced electrochemical properties [27]. The maximum conductivity found for these hybrid materials is $10^{-4}-10^{-5} \mathrm{~S} / \mathrm{cm}$ at room temperature.

In this study, we prepared novel nanostructured organic-inorganic hybrid solid electrolytes using a combination of sol-gel route and organic polymerization. The strategy chosen was to prepare a covalent hybrid organic-inorganic material (hybrid Class II) using a di-epoxy organic component, ethylene glycol diglycidyl ether (EGDE), directly bonded to the hybrid component, 3-glycidoxipropyl trimethoxysilane (GPTMS), through the epoxy ring-opening using $n$-methylimidazole ( $n$-MI). On the other hand, inorganic polycondensation reactions of alkoxide groups were produced from GPTMS. Trimethylethoxysilane (TMES) was used as blocking agent for residual $\equiv \mathrm{Si}-\mathrm{OH}$ groups derived from hydrolysis and condensation of GPTMS in order to avoid contribution of proton conductivity. Lithium 
bis(trifluoromethane)sulfonamide, $\mathrm{LiN}\left(\mathrm{CF}_{3} \mathrm{SO}_{2}\right)_{2}$ (LiTFSI) was used as lithium source.

Finally, we expect that the $\mathrm{Si}-\mathrm{O}-\mathrm{Si}$ backbone, that provides thermal stability and mechanical strength, will be connected with the organic component by the pseudo PEO-chain, which provides good flexibility and processability. One of the aim of this work is study the effect of organic/inorganic and $[\mathrm{O}] /[\mathrm{Li}]$ ratios on the electrochemical properties and the analysis of evaluation the organic polymerization through epoxide ring opening, in order to establish structure-conductivity relationships. An illustration of the expected hybrid structure after polymerization can be observed in Fig. 1, showing the interaction of Li ions with oxygens of the silica-poly(ethylene oxide) hybrid network.

\section{Experimental}

\subsection{Materials}

The materials were prepared using GPTMS, 98\% as hybrid precursor, EGDE, 99\% as organic monomer and TMES, 95\%, all of them commercially available reagents, were obtained from ABCR Company and used as received. $n$-methylimidazole (n-MI, 99\%) from Sigma-Aldrich was used as a initiator for the copolymerization of the epoxy group. LiTFSI, 99.95\% purchased in Sigma-Aldrich was transferred from its air-free packaging into a vial inside a glove box, and then dried at $120^{\circ} \mathrm{C}$ in a glove box (Argon inert atmosphere) for three days before use. Lithium salt can be incorporated in the sol-gel solution for the preparation of electrolytes with various lithium concentrations (for a $\left[\mathrm{Li}^{+}\right] /[\mathrm{O}]$ ratio, where $\mathrm{O}$ represents the oxygen atom concentration derived from the epoxy groups from GPTMS and EGDE). Absolute ethanol (EtOH, 99.5\%) from Panreac was distilled and stored over $4 \AA$ molecular sieves (Karl-Fischer titration $\leq 55 \mathrm{ppm})$ and used as solvent.

\subsection{Preparation of the solid hybrid organic-inorganic electrolytes}


The synthesis involves the initial formation of the organic network (oxidic backbone) and then the development of inorganic environments generating by hydrolysis and condensation reactions. The final step consists of blocking $\equiv \mathrm{Si}-\mathrm{OH}$ and dissolution of the lithium salt to establishing the organic-inorganic Li-electrolyte.

\subsubsection{Synthesis of the functionalized oxidic backbone}

An amount of GPTMS (1 mol) was mixed with variable amounts of EGDE (0.7 to $3.0 \mathrm{~mol})$ in dried ethanol to homogenize. After 30 minutes stirring at room temperature, $n$-MI was added to the mixture in a molar ratio $n$-MI: epoxy groups of 1:25 (0.04 mol $n$-MI/ mol of epoxy groups) and then polymerized at $60{ }^{\circ} \mathrm{C}$ for $10-14$ hours to obtain a nearly complete ring opening based on Popall and coworkers measurements [25].

\subsubsection{Polycondensation of 3 -(glycidoxypropyl)trimethoxysilane}

In the second step, siloxane groups (from GPTMS) were hydrolyzed at room temperature for 3 hours with appropriate amounts of acidic water $\left(\mathrm{HCl} 1 \mathrm{~N} / 1.5 \mathrm{~mol} \mathrm{H}_{2} \mathrm{O}\right.$ relative to $\left.\mathrm{Si}\right)$ to form the $-\mathrm{Si}-\mathrm{O}-\mathrm{Si}$ - linkages to finally produce the silicate framework. In order to block remaining $\equiv \mathrm{Si}-\mathrm{OH}$ units resulting from hydrolysis and condensation reactions and avoid possible proton conductivity effects, the mixture was reacted with an excess of trimethylethoxysilane ( $30 \%$ molar of GPTMS). The solution is cooled at $-2{ }^{\circ} \mathrm{C}$ and then 0.3 mol of TMES is added dropwise while the mixture is stirred at room temperature for 3 hours.

\subsubsection{Establishing the inorganic-organic Li-electrolyte}

Finally, appropriate amounts of lithium salt, LiTFSI, were added into the solution to achieve the desired $\left[\mathrm{Li}^{+}\right] /[\mathrm{O}]$ ratios and stirred for 1 hour at room temperature to obtain a homogeneous solution. The resulting solution was cast onto Teflon dishes and deposited on 
glass slides in order to obtain solid lithium conductors. Coatings were deposited at room temperature in a glove box by a conventional dip-coating process onto soda-lime glass slides $\left(2.5 \times 7 \mathrm{~cm}^{2}\right)$ using a withdrawal rate between 4.5 and $18.8 \mathrm{~cm} \mathrm{~min}^{-1}$, dried at room temperature for $30 \mathrm{~min}$ and heat treated at $100{ }^{\circ} \mathrm{C}$ (heating rate $1{ }^{\circ} \mathrm{C} / \mathrm{min}$ ) in an oven (HOBERSAL Model JB-15) inside the glove box for $12 \mathrm{~h}$ to complete the drying and curing process. The solution was also cast in Teflon $(6 \mathrm{~cm}$ diameter) moulds, dried for 2 days at room temperature and heat treated $100{ }^{\circ} \mathrm{C}$ (heating rate $1{ }^{\circ} \mathrm{C} / \mathrm{min}$ ) for $12 \mathrm{~h}$ to get transparent and crack-free self-supported membranes. All the procedures and material handlings were carried out in argon-filled glove box $\left(\mathrm{H}_{2} \mathrm{O}\right.$ and $\left.\mathrm{O}_{2} \leq 5 \mathrm{ppm}\right)$. The resulting solid hybrid electrolytes were designated as GTE- $X$, where $\mathrm{G}$ represents 3(glycidoxypropyl)trimethoxysilane (GPTMS), $\mathrm{T}$ corresponds to trimethylethoxysilane (TMES), E stands for ethylene glycol diglycidyl (EGDE), and the number $X$ indicates different compositions by varying the GPTMS/EGDE and $\left[\mathrm{Li}^{+}\right] /[\mathrm{O}]$ ratios. Table 1 summarizes the compositions.

\subsection{Characterization}

The viscosity of different sols was measured at $25{ }^{\circ} \mathrm{C}$ by a Vibro Viscometer AX-SV-34 (A\&D Ltd. Co.). Coating thickness was obtained by profilometry (Talystep, Taylor-Hobson UK) as a function of the withdrawal rate. Mechanical properties of solid electrolytes were investigated by their tensile strength. Samples of $5 \mathrm{~mm}$ wide and $30 \mathrm{~mm}$ long were cut from polymer films and tested on a MTS Sinergie 2000 universal testing machine at $25^{\circ} \mathrm{C}$ with 100 $\mathrm{N}$ capacity load cell.

Thermal stability of the hybrid electrolytes was studied by Thermogravimetric Analysis (TGA) in argon up to $900{ }^{\circ} \mathrm{C}$ with a heating rate of $10{ }^{\circ} \mathrm{C} / \mathrm{min}$ using a Netzsch STA 409. DSC scans were performed using a DSC 220U SEIKO calorimeter, by initial cooling (at $5{ }^{\circ} \mathrm{C}$ $\min ^{-1}$ ) from room temperature to $-100{ }^{\circ} \mathrm{C}$, the temperature was maintained at $-50{ }^{\circ} \mathrm{C}$ over 
$10 \mathrm{~min}$, then raised (also at $5{ }^{\circ} \mathrm{C} \min ^{-1}$ ) to $100{ }^{\circ} \mathrm{C}$, and finally cooled (at $5{ }^{\circ} \mathrm{C}$ min ${ }^{-1}$ ) from Perkin Elmer Spectrum 100 spectrometer in the $650-1650 \mathrm{~cm}^{-1}$ range using the Attenuated Total Reflectance (ATR) accessory with a resolution of $2 \mathrm{~cm}^{-1}$. Ring open polymerization (ROP) was followed by FTIR through the measurement of solutions spectra at different times. Raman spectra of the hybrids were recorded in the range $200-1600 \mathrm{~cm}^{-1}$ using a Confocal Raman Microscope (model alpha300 WITec GmbH, Germany). Laser with $532 \mathrm{~nm}$ wavelength excitation was used for this purpose. Several spectra have been performed to obtain an average spectrum.

The ionic conductivity of hybrid electrolytes was measured by Electrochemical AC Impedance Spectroscopy (EIS) using a potentiostat/galvanostat (BioLogic VMP3 Versatile Multichannel) with a two electrodes device, the frequency range was between $10^{6}$ and $0.1 \mathrm{~Hz}$ (60 points/decade) with an amplitude voltage of $50 \mathrm{mV}$. Membranes (with thickness between 0.42 and $1.15 \mathrm{~mm}$ ) were sandwiched between two polished stainless steel blocking electrodes in a glove box under argon atmosphere. The electrical contact between sample and electrodes (area $0.01 \mathrm{~cm}^{2}$ ) were achieved using silver conductive paint (Electrolube $\left.{ }^{\circledR}, \mathrm{UK}\right)$. Before the impedance measurements, the sample was kept at $100{ }^{\circ} \mathrm{C}$ in inert atmosphere (Ar) for $12 \mathrm{~h}$, then the temperature was decreased to RT while measuring conductivity. The measurements were performed in the temperature range of 20 to $100{ }^{\circ} \mathrm{C}$ in a closed inert atmosphere (Ar) beaker cell, and the system was thermally equilibrated at each selected temperature for at last one hour.

The ionic conductivity $\sigma$ of the samples in the transverse direction was calculated from the impedance data by Eq.(1):

$$
\sigma=\frac{t}{R_{c t} S}
$$


where $R_{c t}$ is the electrolyte resistance obtained from the intersection of the semicircle with the electrode area of the sample, respectively.

The electrochemical stability windows (ESW) of the hybrid electrolytes was determined by cyclic voltammetry (CV) using stainless steel (SS) as a working electrode and lithium metal as counter and reference electrodes with the asymmetrical structure Li | SHE | SS using a Swagelok® type cell at scan rate of $5 \mathrm{mV} \mathrm{s}^{-1}$ from 0.5 to $7.0 \mathrm{~V} \mathrm{vs.} \mathrm{Li} / \mathrm{Li}^{+}$.

The lithium-ion transference number $\left(t_{L i}{ }^{+}\right)$of the hybrid electrolytes at $25 \mathrm{C}$ was measured by a combination measurement of $a c$ impedance and $d c$ polarization using a symmetric cell of $\mathrm{Li}$ metal | SHE | Li metal, as described by Evans [28], using a Swagelok® type cell. The surface of lithium metal was shaved with a scalpel before use. The cell was assembled in a glove box $\left(\mathrm{H}_{2} \mathrm{O}\right.$ and $\left.\mathrm{O}_{2}<5 \mathrm{ppm}\right)$. The cell was firstly applied a $d c$ voltage $(\Delta V(\mathrm{mV})$, and $300 \mathrm{mV}$ in this study) until a steady current was obtained (usually 14-16 hours in this study), and the initial $\left(I_{\mathrm{o}}\right)$ and steady $\left(I_{\mathrm{ss}}\right)$ currents $(\mu \mathrm{A})$, which flow through the cell, were measured. Simultaneously, the impedance spectra of the cell were recorded in the frequency range from $10^{6}$ to $0.01 \mathrm{~Hz}$ with an oscillation voltage of $10 \mathrm{mV}$, before and after the $d c$ polarization, to obtain the initial $\left(R_{\mathrm{i}}\right)$ and final $\left(R_{\mathrm{f}}\right)$ resistances $(\Omega)$ of the electrolyte, and the initial $\left(R_{I}{ }^{0}\right)$ and final $\left(R_{I}^{s s}\right)$ resistances $(\Omega)$ of interfacial layers of the Li metal electrode/electrolyte. On the base of these values measured for the parameters above, the lithium-ion transference number $\left(t_{L i}{ }^{+}\right)$was then calculated by Eq.(2):

$$
t_{L i^{+}}=\frac{I_{S S} R_{f}\left[\Delta V-I_{0} R_{I}^{0}\right]}{I_{0} R_{i}\left[\Delta V-I_{S S} R_{I}^{S S}\right]}
$$

Thin-film batteries consisting of commercial lithium metal as anode, GTE-2 as solid electrolyte (this work) and $\mathrm{Li}_{4} \mathrm{Ti}_{5} \mathrm{O}_{12}$ films developed in a previous article [29] as cathode have been assembled. The microbattery has been fabricated inside a glove box filled with argon using a quartz substrate with a $60 \mathrm{~nm}$ gold coating (as current collector) and the 
$\mathrm{Li}_{4} \mathrm{Ti}_{5} \mathrm{O}_{12}$ film with a thickness of $125 \mathrm{~nm}$. The experimental procedure for the preparation of this electrode is described elsewhere [30]. Then, the hybrid solid electrolyte coating $(800 \mathrm{~nm})$ on the cathode has been prepared by dipping using a withdrawal rate of $16 \mathrm{~cm} / \mathrm{min}$, covering the entire cathode surface (Fig. 2). The coating is dried at room temperature for several days before the lithium foil is placed on the surface of the electrolyte coating. This drying leads to the formation of a soft electrolyte coating that can easily accommodate the lithium foil, improving the surface contact between the electrolyte and anode. Finally, a thermal treatment at $120{ }^{\circ} \mathrm{C}$ for 12 hours is carried out to consolidate the electrolyte and to enhance the bonding between the three components of the microbattery. A piece of $\mathrm{Cu}$ foil is attached as anode current collector on the Li anode, and then, after fixing the wires on both electrodes, all the microbattery is protected by the tesa ${ }^{\circledR} 51408$, a flame retardant polyimide masking tape. Cycling of the thin-film microbattery was performed at $1.0 \mu \mathrm{A} / \mathrm{cm}^{2}$, in an argon filled beaker cell using cut-off voltages at 2.0 and $1.0 \mathrm{~V}$ versus $\mathrm{Li} / \mathrm{Li}^{+}$.

\section{Results and discussion}

\subsection{Solutions, thin-films and self-supported electrolytes characterization}

GTE sols are homogeneous and slightly yellowish with no phase separation or precipitates with a $\mathrm{pH}$ of 9.0 and viscosity values of as prepared sols at room temperature between 7.3 and $8.7 \mathrm{mPa}$ s depending on lithium content and EGDE organic precursor. The stability of the sols was evaluated through $\mathrm{pH}$ and viscosity measurements at $25^{\circ} \mathrm{C}$ as a function of aging time. Rheological properties were not affected during the aging of the sols, and their viscosity and $\mathrm{pH}$ do not exhibit significant changes after several weeks and remain very stable even after several months.

The procedure provided flexible and easy to handle self-supported membranes with thickness between 326 and $651 \mu \mathrm{m}$. Hybrid membranes without lithium (GTE-5) are homogeneous, 
transparent and crack-free after the heat treatment at $100{ }^{\circ} \mathrm{C}$. Incorporation of small amounts the self-supported membranes keeping flexibility and absence of cracks (Fig. 3a). When EGDE content is increased from 40 to $60 \mathrm{~mol} \%$ in the G:E molar ratio (Table 1) no significant changes were appreciated in the membrane formation. However, for further increments in EGDE content ( $75 \mathrm{~mol} \%)$ no membranes were consolidated, resulting in gel type materials. In the same way, when $\mathrm{Li}$ content increased from $\left[\mathrm{Li}^{+}\right] /[\mathrm{O}]=0.07$ to 0.20 for 50 mol\% EGDE (GTE-6, GTE-2, and GTE-7), no changes in structural consolidation were observed. For higher lithium content $\left(\left[\mathrm{Li}^{+}\right] /[\mathrm{O}]=0.40, \mathrm{GTE}-8\right)$ no self-supported membranes were consolidated even after several thermal treatments, possibly due to the wide dispersion of the negative charge of LiTFSI anion [31], causing a plasticizing effect resulting in the formation of complexes with the poly(ethylene oxide) chains $\left(-\mathrm{OCH}_{2} \mathrm{CH}_{2}-\right)_{n}$.

Fig. $3 b$ shows photographs of heat treated hybrid thin-films using a withdrawal speed of 4.5 $\mathrm{cm} \min ^{-1}$ for GTE-2 composition with $\left[\mathrm{Li}^{+}\right] /[\mathrm{O}]=0.1$ and without lithium salt (GTE-5) for 50 mol\% EGDE compositions. Homogeneous and transparent coatings with high optical quality and without apparent precipitates were obtained. No physical changes were observed when $\mathrm{Li}$ or EGDE content was changed. Different compositions show a highly homogeneity that suggests no phase separation, indicating that organic and inorganic components, and $\mathrm{Li}$ precursors were blended at molecular level [32]. Profilometry measurements indicate an average thickness between 0.8 and $1.0 \mu \mathrm{m}$ as a function of withdrawal rates and composition. Sols with higher amount of Li present higher viscosities and produce thicker coatings with the same withdrawal rate.

\subsection{Mechanical properties}

Mechanical measurements were preformed on solid hybrid electrolytes using a tensile tester in order to determine the tensile strength. 4.5 MPa was obtained for GTE-2 composition 
(50\%EGDE, $0.10[\mathrm{Li}] /[\mathrm{O}])$. The increasing of EGDE decreases the strength, but GTE-1 and

\subsection{Thermal properties of solid hybrid electrolytes}

Thermal stability of hybrid self-supported electrolytes without thermal treatment was investigated by thermogravimetric analysis (TGA) in inert atmosphere. TGA curves of hybrid electrolytes with different EGDE and $\left[\mathrm{Li}^{+}\right] /[\mathrm{O}]$ contents were shown in Fig. 4 a).

For all the compositions two steps of weight losses were noticed within the temperature range of measurement. The soft weight around $8 \%$ change up to $180^{\circ} \mathrm{C}$ is assigned to evaporation of physically adsorbed water and ethanol (products of the polycondensation reactions), which is often observed in sol-gel-derived materials [33]. A second region, between 180 and $400^{\circ} \mathrm{C}$, shows weight loss around $45 \%$, corresponding to a degradation of sulfonamide groups (TFSI) and the polyethylene combustion and evolution of polycondensation reactions [34]. It was found that the GTE-7 composition with the highest Li concentration present lower thermal decomposition temperature. The decrease in the electron density due to the interactions of $\mathrm{Li}^{+}$ ions with the oxygen atoms might weaken the $\mathrm{C}-\mathrm{O}$ bonds, causing a decrease in the decomposition temperature with the increase in LiTFSI concentrations [24]. Above $400^{\circ} \mathrm{C}$, the samples continue to decompose slowly. It is clear that these solid electrolytes are thermally stable up to $250^{\circ} \mathrm{C}$, which is far higher than the operating temperature of lithium ion batteries $\left(40-70^{\circ} \mathrm{C}\right)$.

Fig. $4 \mathrm{~b}$ shows the DSC thermograms of the hybrid electrolytes with various $[\mathrm{O}] /[\mathrm{Li}]$ and EGDE ratios. The $\mathrm{Tg}$ value of the electrolytes increases with the increase in lithium salt 
concentrations. The change in the $\mathrm{Tg}$ value from $-61^{\circ} \mathrm{C}$ at $[\mathrm{O}] /[\mathrm{Li}]=0.07$ to $-45^{\circ} \mathrm{C}$ at $[\mathrm{O}] /[\mathrm{Li}]=$ 0.20 reflects the increase in the chain rigidity with salt concentrations. The interaction between oxygen of the polyethylene oxide units and the lithium cation helps in the progressive increase of $\mathrm{Tg}$ of the complex as the extent of the intermolecular interaction increases with increasing salt concentrations [32]. The increased of crosslinking degree (increase GPTMS content) enhancing the Tg and decreasing the mobility of the PEG chains and the ionic conductivity. No melting transition was observed for all compositions studied suggesting a complete amorphous nature of the hybrid electrolytes. Tm is not observed because the silica network covalently bonded to organic network has an important effect on the crystallization, polyethylene oxide chains are bonded with the 3D-silica networks suppressing tending to crystallization due to the restrictions imposed by the silica network. As the polymer segments are flexible in the amorphous phase, this amorphous hybrid solid electrolyte generally has a higher conductivity.

\subsection{Structural characterization}

FTIR and Raman spectroscopy were used to study the chemical structure of the organicinorganic hybrid electrolytes with various EGDE content and $\left[\mathrm{Li}^{+}\right] /[\mathrm{O}]$ ratios.

\subsubsection{FTIR spectroscopy}

Spectroscopic studies allow the analysis of the hybrid network formation, demonstrating the interaction of $\mathrm{Li}^{+}$with hybrid materials. Fig. 5a represents the $1750-650 \mathrm{~cm}^{-1}$ FTIR spectral region of self-supported heat treated membranes with different EGDE content. The spectrum consisted of strong absorption bands in the range of $1260-1000 \mathrm{~cm}^{-1}$ related to $\mathrm{Si}-\mathrm{O}-\mathrm{Si}$ and $\mathrm{Si}$ O-C hybrid network formation [34,36]. In the first region, intense bands at $1054 \mathrm{~cm}^{-1}$ and $1094 \mathrm{~cm}^{-1}$ are observed and correspond to $\mathrm{Si}-\mathrm{O}-\mathrm{C}$ stretching vibration mode and asymmetrical $\mathrm{Si}-\mathrm{O}-\mathrm{Si}$ vibration mode respectively, confirming formation of hybrid structure, 
[36]. An intense and broad band located at $\sim 1189 \mathrm{~cm}^{-1}$ is also observed related to $v_{\text {as }}(\mathrm{Si}-\mathrm{O}-$

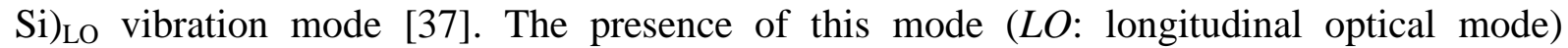
suggests some structural long-range order according to some authors and indicates homogeneity and compatibility between organic and inorganic components at molecular level [32]. The disappearance of the band at $1030 \mathrm{~cm}^{-1}$ associated to $v_{\text {as }}(\mathrm{Si}-\mathrm{O}-\mathrm{C}-$ ) vibration from $\equiv \mathrm{Si}-\left(\mathrm{O}-\mathrm{CH}_{3}\right)_{3}$ and appearance of $845 \mathrm{~cm}^{-1}$ and $788 \mathrm{~cm}^{-1}$ bands associated to crosslinking $v(\mathrm{Si}-\mathrm{O}-\mathrm{Si}-)$ and $v_{\mathrm{s}}(\mathrm{Si}-\mathrm{O}-\mathrm{Si})$ vibrations, respectively [38], confirms the total hydrolysis of GPTMS. No bands related to epoxide groups such as $1260 \mathrm{~cm}^{-1}$ (breathing ring deformation) and $912 \mathrm{~cm}^{-1}$ (symmetrical stretching mode) indicates a complete ring opening Residual silanol groups attached to the hybrid network (shoulder $956 \mathrm{~cm}^{-1}$ ) confirms the almost complete blocking reaction with TMES [36].

The bands related to TFSI ${ }^{-}$anion vibrations appear in the range of $1360-1130 \mathrm{~cm}^{-1}$. A doublet located at $1353 \mathrm{~cm}^{-1} / 1332 \mathrm{~cm}^{-1}$ and a shoulder at $1137 \mathrm{~cm}^{-1}$ corresponds to asymmetric and symmetric (out of plane) stretching vibrations modes of $\mathrm{SO}_{2}$ groups, respectively [39]. The band at $1228 \mathrm{~cm}^{-1}$ and $\sim 1189 \mathrm{~cm}^{-1}$ are associated to $v_{\mathrm{s}} \mathrm{CF}_{3}$ and $v_{\mathrm{as}} \mathrm{CF}_{3}$ and overlap with silica vibration stretching modes [40]. The intensity of those bands increase with EGDE, suggesting that $\mathrm{Li}^{+}$is present as free cation coordinated with $\mathrm{O}-\mathrm{CH}_{2}-\mathrm{CH}_{2}-\mathrm{O}-$ chains but could also appear coordinated with TFSI ${ }^{-}$anions $[34,37]$. Weak bands located at $740 \mathrm{~cm}^{-1}$ and the singlet at $\sim 654 \mathrm{~cm}^{-1}$ associated to $v_{\mathrm{s}}(\mathrm{S}-\mathrm{N}-\mathrm{S})$ and $\delta(\mathrm{SNS})$ modes, respectively, are representative of dissociated ionic species of free imide ions which is consistent with previous results $[39,41]$. Fig. 5b represents $1750-650 \mathrm{~cm}^{-1}$ FTIR liquid spectral region of different $\left[\mathrm{Li}^{+}\right] /[\mathrm{O}]$ compositions. The intensity of $1353 / 1330 \mathrm{~cm}^{-1}$ and $1137 \mathrm{~cm}^{-1}$ bands increase with lithium content indicating a greater proportion of free imide ions. A band at $880 \mathrm{~cm}^{-1}$ associated to $\mathrm{C}-$ $\mathrm{OH}$ stretching vibration mode indicates the presence of ethanol (solvent of sol-gel solutions) and a band at $956 \mathrm{~cm}^{-1}$ are related to $\mathrm{Si}-\mathrm{OH}$ vibration bonds which can be minimized after 
heat treatment as was shown in Fig. 4a. A shoulder near $\sim 940 \mathrm{~cm}^{-1}$ was observed, corresponding to $v_{\mathrm{s}}(\mathrm{C}-\mathrm{O}) / \mathrm{v}(\mathrm{C}-\mathrm{C})$ vibration modes, confirming the total polymerization of epoxide groups. Similar spectroscopic profiles were observed for different $\left[\mathrm{Li}^{+}\right] /[\mathrm{O}]$ rates and EGDE content and only small differences in terms of intensity are observed, confirming that hybrid network was formed and a good distribution of ionic species in all GTE compositions [42]. Table 2 shows the main absorption bands for the precursors and the hybrid GTE network [32-42].

\subsubsection{Crosslinking degree of GPTMS/EGDE precursors by FTIR spectroscopy}

Fig. 5c shows the crosslinking degree of GTE-2 composition $\left(50 \%\right.$ EGDE, $\left.\left[\mathrm{Li}^{+}\right] /[\mathrm{O}]=0.1\right)$ as a function of time during the organic network formation carried out at $60{ }^{\circ} \mathrm{C}$. The extent of epoxy reaction (ROP) of GPTMS/EGDE hybrids were determined by the decrease in peak intensity of epoxy band located at $912 \mathrm{~cm}^{-1}$ related to symmetrical stretching mode in epoxide rings. The crosslinking degree $(\varphi)$, is thus given by Eq. (3) [43]:

$$
\varphi=1-\frac{i_{t}}{i_{0}}
$$

where $i_{0}$ and $i_{t}$ refer to the peak intensity of the reference band $\left(912 \mathrm{~cm}^{-1}\right)$ at time zero $(0)$ and after certain time $(t)$, respectively. It is also possible to show the increase in band at $\sim 956 \mathrm{~cm}^{-1}$ and a shoulder at $\sim 940 \mathrm{~cm}^{-1}$ corresponding to $v(\mathrm{Si}-\mathrm{OH}) \quad[35]$ and $v_{\mathrm{s}}(\mathrm{C}-\mathrm{O}) / v(\mathrm{C}-\mathrm{C})$, respectively. These results suggest the opening of epoxy ring accompanied to partial hydrolysis of GPTMS precursor due to the presence of $\mathrm{C}-\mathrm{OH}$ groups in the first stage of hybrid synthesis. The polymerization reaction produces about $97 \%$ crosslinking after 5 hours and no evidence of epoxy rings (peak intensity) were shown after 6.5 hours indicating complete polymerization [43].

\subsubsection{Raman spectroscopy}

Fig. 6 is a plot of the Raman spectra in $1200-200 \mathrm{~cm}^{-1}$ region of hybrid thin-films electrolytes on glass substrates with different composition heat treated at $100{ }^{\circ} \mathrm{C}$. Table 3 contains the 
main assignments of Raman bands for precursors and GTE hybrid electrolytes [37-38,41,43reactions are completed [45,47-48]. Also, the intense and broad band at $\sim 1144 \mathrm{~cm}^{-1}$, assigned to $v(\mathrm{C}-\mathrm{O}) / v(\mathrm{C}-\mathrm{O}-\mathrm{C})$ modes $[44]$ and a shoulder at $\sim 1122 \mathrm{~cm}^{-1}$ corresponding to the coupled $v(\mathrm{C}-\mathrm{C}) / \mathrm{CH}_{2}$ wagging [49], confirm the presence of poly(ethylene oxide) chains. The last band is overlapped with $v_{\mathrm{s}} \mathrm{SO}_{2}$ stretching band causing a wider peak. The increase in absorption band at $\sim 1144 \mathrm{~cm}^{-1}$ with EGDE content indicates a lower presence of $\mathrm{Li}^{+}---\mathrm{O}$ (ether) complexes [49]. Vibrational modes of $\mathrm{CH}_{2}$ of PEO have been extensively used to explore the formation of ion pairs $\mathrm{Li}^{+}---\mathrm{O}$ in PEO-like polymer electrolytes and/or $\mathrm{Li}^{+}---\mathrm{TFSI}^{-}$ [44,49-51]. The band at $898 \mathrm{~cm}^{-1}$ is related to $\mathrm{CH}_{2}$ deformation $\left(\mathrm{Li}^{+}---\mathrm{O}\right.$ (ether oxygens)), whereas band at $857 \mathrm{~cm}^{-1}$ is related to a combination band of $\mathrm{C}-\mathrm{O}$ stretch and $\mathrm{CH}_{2}$ rocking vibration, increasing in intensity with Li content [44]. Other interesting region $710-790 \mathrm{~cm}^{-1}$ (Fig. 6 a and $6 \mathrm{~b}$ inlet) is related to $\mathrm{S}-\mathrm{N}-\mathrm{S}$ symmetrical stretching modes of TFSI ${ }^{-}$anion $[32,49,52]$. Three contributions located at $744 \mathrm{~cm}^{-1}, 748 \mathrm{~cm}^{-1}$ and $752 \mathrm{~cm}^{-1}$ correspond to free anions, ion pairs $\left(\mathrm{Li}^{+}---\mathrm{O}\right)$ and $\mathrm{Li}^{+}---\mathrm{TFSI}^{-}$, respectively [46,51]. The free anion contribution increases with EGDE content and the average wavenumber is downshifted. This can be explained as a result of $\mathrm{Li}^{+}---\mathrm{O}$ (ether oxygens) complex formation in agreement with previous results. For higher lithium concentrations $\left[\mathrm{Li}^{+}\right] /[\mathrm{O}]=0.2$, a new weak and broad band at $776 \mathrm{~cm}^{-1}$ appears as shown in Fig. $5 \mathrm{c}$ (devonvolution). This peak corresponds to $\mathrm{CF}_{3}$ deformation mode and is usually attributed to the formation of interactions $\mathrm{Li}^{+}$---TFSI ${ }^{-}$of the lithium salt [46,51] in agreement with FTIR results. In conclusion, higher lithium concentrations cause aggregate formation whereas free anions that can interact with ether oxygens prevail with lower lithium concentrations. 


\subsection{Ionic Conductivity Measurements}

Fig. 7 shows the ionic conductivity $(\sigma)$ as a function of temperature for GTE self-supported membranes heat treated at $100{ }^{\circ} \mathrm{C}$. Fig. 7 a compares the Arrhenius type behavior for GTE compositions with $\left[\mathrm{Li}^{+}\right] /[\mathrm{O}]=0.1$ varying the EGDE content. Fig. 6 b shows the conductivity temperature dependence for GTE compositions for different lithium concentration for $50 \%$ EGDE compositions. In both cases the ionic conductivity increases linearly with increasing temperature, exhibiting Arrhenius-type behavior. Thermally activated processes like these are usual in hybrid electrolyte systems [53]. Arrhenius-type conductivity behavior can be expressed by Eq. (4) as follows:

$$
\sigma=\sigma_{0} \exp \left(-E_{a} / k_{B} T\right)
$$

where $\sigma_{0}$ is the pre-exponential factor, $E_{a}$ is the activation energy and $k_{B}$ is the Boltzmann constant. This Arrhenius-type behavior also indicates that the studied electrolytes present a single transport mechanism (no phase transition) in the temperature range studied $[42,54]$. Table 4 shows the room temperature and $60{ }^{\circ} \mathrm{C}$ ionic conductivity and calculated activation energy for studied GTE compositions. Quite similar activation energy values (between 0.5-0.6 $\mathrm{eV}$ ) were obtained for all compositions, indicating a similar behavior in ionic conduction mechanism. In Fig 7 a the effect of the EGDE content in ionic conductivity for GTE solid hybrid electrolytes is studied. Ionic conductivity increases with EGDE content suggesting that the presence of poly(ethylene oxide) chains play an important role in conduction mechanism [25]. Otherwise, high GPTMS content (low \%EGDE) leads to lower conductivity values which implies that further development of the inorganic network prevents the segmental motion of PEO units and hence the conductivity decreases [22,55]. These results are in agreement with Raman spectroscopic characterization. The presence of free ions and ion pairs and the segmental motion of PEO units facilitate conduction processes [56]. The highest room temperature conductivity value $2.6 \times 10^{-5} \mathrm{~S} / \mathrm{cm}$ was obtained for the self-supported membrane 
in GTE-3 composition (60\% EGDE). Regarding FTIR and Raman results, this hybrid

\subsection{Electrochemical stability window}

The electrochemical stability of the hybrid electrolyte in contact with electrode materials is an essential parameter for providing satisfactory performance in lithium ion battery applications. Fig. 8 shows the electrochemical window at room temperature for GTE-2 composition using a scan rate $\mathrm{dE} / \mathrm{dt}=5 \mathrm{mV} \mathrm{s}^{-1}$. The figure shows the first five $\mathrm{CV}$ curves in the range between 0.5 and $7.0 \mathrm{~V}\left(\mathrm{vs} . \mathrm{Li} / \mathrm{Li}^{+}\right.$). A very low background current was measured in a potential region between -0.5 and $7.0 \mathrm{~V}$ for the cell prepared with the SS electrode. No significant peaks are observed in the CV curves for the voltage range studied, meaning that no secondary chemical reactions or decomposition of the electrolyte against the lithium occurs. It can be seen that the anodic and cathodic peaks are at the endpoints in the voltammogram; the deposition of the $\mathrm{Li}^{+}$ ions (reduction) is observed near the cathodic limit at $-0.5 \mathrm{~V}$ and the oxidation is about $6.3 \mathrm{~V}$ 
[22]. A small and broad anodic peak is detected about 2,2-3,2 $\mathrm{V}$ associated to surface oxidation impurities present in the hybrid [58]. Nevertheless, the intensity of this peak is negligible comparing to the scale $\left(\leq 0,005 \mathrm{~mA} / \mathrm{cm}^{2}\right)$. The process is highly reversible, and cycles retain a good symmetry between its anode and cathode peaks as shown in the figure. Therefore, the range of electrochemical stability of the electrolyte is defined between $1,5-4,9$ $\mathrm{V}\left(\mathrm{vs} . \mathrm{Li} / \mathrm{Li}^{+}\right.$). The oxidation potential of $4.9 \mathrm{~V}$ is quite similar to polymer electrolyte, which exhibit a wide range of electrochemical stability potential with maximum values around 4.0$5.5 \mathrm{~V}$ (vs. $\mathrm{Li} / \mathrm{Li}^{+}$). A wide range of oxidation potential allows the implementation of these materials as electrolytes in lithium ion batteries [59], and ensures good compatibility with a large number of commercial electrodes [60].

\subsection{Transference Number Measurements}

The lithium-ion transference number $\left(t_{L i}{ }^{+}\right)$of hybrid self-supported membranes was calculated by Eq.(2). Note that this equation is a slightly modified version of the original Evans et al. equation taking into account also the modification in the hybrid electrolyte resistance [28]. The Li-ion transference numbers measured at room temperature of the solid hybrid electrolytes are presented in Table 4 . The calculated transference numbers are affected by the phenomena related to ion associations and to lithium passivation layer formation (electrode/solid electrolyte interface, so called SEI: Solid Electrode Interface) [54,59]. Fig. 9 show the chronoamperometric and impedance measurement (inlet) for GTE-2 (50\% EGDE) with lithium concentration of $\left[\mathrm{Li}^{+}\right] /[\mathrm{O}]=0.1$. The equivalent circuit to fit impedance data represents the electrolyte resistance $R_{i}$ or $R_{f}$ in series with the passivation layer resistances $R_{1}^{0}$ or $R_{l}^{S S}$ in the initial and final states, respectively. Solid electrolytes conductivity depends on electrode roughness and other surface phenomena between electrode and electrolyte, so their resistances must be combined with a constant phase element (CPE) that leads to an equivalent 


\subsection{Full battery tests}

Finally, extended cycling of the solid electrolyte GTE under realistic conditions was carried out to demonstrate commercial viability using a $\mathrm{Li}_{2} / \mathrm{Li}_{4} \mathrm{Ti}_{5} \mathrm{O}_{12}$ cells. In addition, evaluation of full cells using known anode materials systems over significantly larger number of cycles was performed. Fig. 10a displays four representative galvanostatic discharge-charge profiles of the microcell prepared using lithium metal as anode, GTE-2 as solid electrolyte and $\mathrm{Li}_{4} \mathrm{Ti}_{5} \mathrm{O}_{12}$ films as cathode, and a current density of $1.0 \mu \mathrm{A} / \mathrm{cm}^{2}$. The cell was first discharged to $1.0 \mathrm{~V}$, and then charged and discharged between $1.0 \mathrm{~V}$ and $2.0 \mathrm{~V}$. The data are plotted as cell voltage 
versus capacity ( $\mathrm{mA} \mathrm{h} / \mathrm{g}$ ), based on the weight of cathode film. The first discharge of this cell is represented by

$$
\begin{aligned}
& \mathrm{Li}_{4} \mathrm{Ti}_{5} \mathrm{O}_{12}+3 \mathrm{Li}^{+}+3 \mathrm{e}^{-}=\mathrm{Li}_{7} \mathrm{Ti}_{5} \mathrm{O}_{12} \text { (cathode) (5) } \\
& 3 \mathrm{Li}=3 \mathrm{Li}^{+}+3 \mathrm{e}^{-} \text {(anode) }(6)
\end{aligned}
$$

A capacity loss is observed during the first charge step because some lithium ions are not extracted from the cathode after the first discharge. This behaviour can be associated in part to the low cutoff voltage $(2.0 \mathrm{~V})$, but may be due also to the growth of a surface layer on the cathode film surface. After the first cycle there is trend change, and the capacity values of charge steps are higher than discharge steps. This performance is related to the surface layer that began to form during the first cycle, which slows the movement of lithium ions. The following cycles represented in the figure show a similar behaviour and a reduction in discharge and charge capacities as a result of the gradual degradation of the cell interfaces.

Fig. $10 \mathrm{~b}$ shows the discharge capacities vs. cycle number of the same microcell. As already mentioned in the above discussion, a continuous decrease in the capacitance values due to the gradual deterioration of the system is observed. Although these results are preliminary, the test to elucidate if the hybrid solid electrolyte developed in this work can be used in a microbattery has been successful as evidenced by the good performance shown during 500 cycles. This fact is in agreement with the observed resistance increase in the cell during the transference number measurement that is closely related to the deteriorate interface between solid electrolyte and electrodes, causing the capacity fading. Although these results are preliminary, the test to elucidate if the hybrid solid electrolyte developed in this work can be used in a microbattery has been successful as evidenced by the good performance, retaining a capacity of $0.8 \mathrm{mAh} / \mathrm{g}$ after 500 cycles. This fact makes these hybrid organic-inorganic materials promising candidates as solid electrolytes for Li-ion batteries. The search of the 
optimal cycling conditions for cells based on these hybrid solid electrolytes, as well as the study of similar cells comprising other anode and cathode materials, are in progress.

\subsection{Compatibility with metal lithium}

The stability of lithium interface was investigated by monitoring the time dependence of the impedance of Li/solid electrolyte/LTO cells. The compatibility between solid electrolyte and lithium anode, which can be evaluated by the interfacial impedance $\left(\mathrm{R}_{\mathrm{i}}\right)$, is a key factor for application in a lithium ion battery. Fig. 10c displays the variation of interfacial resistance as a function of time for the solid hybrid electrolyte GTE-2 composition. It is clear that the amplitude of the middle-frequency semicircle shows a substantial progressive increase upon 500 cycles. This is a clear indication of an increase of the interfacial resistance and thus, of a continuous growth of the passivation layer (SEI). Therefore, one may conclude that these solid hybrid electrolytes show a moderate stability against $\mathrm{Li}$ in agreement with the capacity fading during cycling.

\section{Conclusions}

Homogeneous hybrid organic-inorganic solid electrolytes based on a silica star-branched ethylene oxide network with LiTFSI were successfully synthesized combining polymerization of epoxide groups and inorganic polycondensation by sol- gel method. FTIR and Raman investigations confirm the interactions of different components at molecular level and also the interaction of $\mathrm{Li}$ ions with $\mathrm{O}-\mathrm{CH}_{2}-\mathrm{CH}_{2}-\mathrm{O}-$ chains. The favorable mechanical properties and thermal stability established the practical usefulness of the hybrid electrolyte. The ionic conductivity increases with EGDE content up to $2.6 \times 10^{-5} \mathrm{~S} / \mathrm{cm}$ at room temperature. Conductivity also increases with $\left[\mathrm{Li}^{+}\right] /[\mathrm{O}]$ ratio, enhancing up to 0.10 , and then decreases for $\left[\mathrm{Li}^{+}\right] /[\mathrm{O}]=0.20$ as a result of a decrease in the number of mobile ions, and the higher crosslinking and formation of ion-pairs $\left(\mathrm{Li}^{+}-\mathrm{TFSI}^{-}\right)$. The best combination of ionic conductivity 
and mechanical properties was obtained for 50GPTMS-50EGDE $\left[\mathrm{Li}^{+}\right] /[\mathrm{O}]=0.10$. Wide electrochemical stability and charge-discharge tests confirm that these hybrid materials are promising candidates as solid electrolytes for Li-ion batteries.

\section{Acknowledgments}

This work has been supported by the Spanish Science and Innovation Ministry under project PLE2009-0074 from National Program for I + D internationalising (ACI-PLAN E) and Japanese Science and Technology Agency (JST). J. Mosa acknowledgments European Social Fund (ESF) and Community of Madrid (CM, Spain) (PILCONAER S2013/MAE-2975) for financial support. The authors wish to thank Prof. K. Tadanaga for a fruitful collaboration, and M. Gómez and Dr. A. del Campo for their help in the experimental procedure. 


\section{References}

1. D. Saikia, T.-H. Wang, C.-J. Chou, J. Fang, L.-D. Tsai, H. Ming, RSC Adv. 5 (2015) 42922 .

2 E. Quartarone, P. Mustarelli, Chem. Soc. Rev. 40 (2011) 2525.

3 D. T. Hallinan, N. P. Balsara, Annu. Rev. Mater. Res. 43 (2013) 503.

4 H. Aydin, A. Bozkurt, J. Mater. Research 29(5) (2014) 625.

5 K. K. Kumar, M. Ravi, Y. Pavani, S. Bhavani, A. K. Sharma, V. V. R. N. Rao, J.Membr.Sci. 454 (2014) 200.

6 F.Deng, X. Wang, D. He, J. Hu, C. Gong, Y. S. Ye, X. Xie, Z. Xue, J. Membr. Sci. 491 (2015) 82.

7 K. Ramanjaneyulu, N. Bar, M. S. A. S. Shah, S. V. Manorama, P. Basak, J. Power Sources 217 (2012) 29.

8 X. Liang, Y. Yang, X. Jin, Z. Huang, F. Kang, J. Membr. Sci.493 (2015) 1.

9 G. Y. Jung, J. H. Choi, J. K. Lee, Adv .Polym. Technol. 21499 (2015) 1.

10. Y. L. Nimah, M. -Y. Cheng, J. H. Cheng, ,J. Rick, B .-J. Hwang, J. Power Sources 278 (2015) 375.

11 W.H. Hou, C.Y. Chen, C.C. Wang, Y.H. Huang, Electrochim. Acta 48 (2003) 679.

12 L.M. Bronstein, R.L. Karlinsey, K. Ritter, C.G. Joo, B. Stein, J.W. Zwanziger, J. Mater. Chem. 14 (2004) 1812.

13 S.C. Nunes, V. de Zea Bermudez, M.M. Silva, S. Barros, M.J. Smith, E. Morales,L.D. Carlos, J. Rocha, Solid State Ion. 176 (2005) 1591.

14 D.M. Tigelaar, M.A.B. Meador, J.D. Kinder, W.R. Bennett, Macromolecules 39 (2006) 120.

15 H.-M. Kao, T.-T. Hung, G.T.K. Fey, Macromolecules 40 (2007) 8673.

16 D. Saikia, Y.-H. Chen, Y.-C. Pan, J. Fang, L.-D. Tsai, G.T.K. Fey, H.-M. Kao, J. Mater. Chem. 21 (2011) 10542.

17 C. O. Avellaneda, K. Dahmouche, L. O. S. Bulhoes, A. Pawlicka, J. Sol-Gel Sci. Technol. 19 (2000) 447.

18 M. Fernandes, L. C. Rodrigues, R. A. S. Ferreira, A. Gonçalves, E. Fortunato, M. M. Silva, M. J. Smith,L. D. Carlos, V. de Zea Bermudez, Solid State Ion. 204-205 (2011) 129.

19 M. Hajzeri, M. Colovic, A. S. Vuk, U. Posset, B. Orel, Mater. Tehnol. 45(5) (2011) 433.

20 C.-C. Liao, H.-Y.Wu, D.Saikia, Y.-C.Pan, Y.-K.Chen, G.T.K.Fey, H.-M.Kao, Macromolecules 41 (2008) 8956.

21 D. Saikia, C.-G. Wu, J. Fang, L.-D. Tsai, H.-M. Kao,J. Power Sources 269 (2014) 651.

22 D. Saikia, H.-Y. Wu, C.-P. Lin, Y.-P. Pan, J. Fan, L.-D. Tsai, G.T.K. Fey, H.-M. Kao, Polymer, 53 (2012) 6008.

23 H.-Y. Wu, D. Saikia, C.-P. Lin, F.-C. Wu, G.T.K. Fey, H.-M. Kao, Polymer, 51 (2010) 4351.

24 T.-S. Hu, P.-K. Hong, D. Saikia, H.-M. Kao, M.-CF. Chen, Ionics 20 (2014) 1561.

25 M. Popall, H. Durand, Electrochim. Acta, 37 (1992) 1593.

26. J. Zhang, C. Ma, J. Liu, L. Chen, A. Pan, W. Wei, J. Memb. Sci. 509 (2016) 138.

27. M. Yanilmaz, Y. Lu, J. Zhu, X. Zhang, J. Power Sources 313 (2016) 205.

28 J. Evans, C.A. Vincent, P.G. Bruce, Polymer, 28 (1987) 2324.

29. C.J. Brinker, K.D Keefer, D.W Schaefer, C.S Ashley, J. Non-Cryst. Solids 48 (1982) 47.

30 J. Mosa, M. Aparicio, K. Tadanaga, A. Hayashi, M. Tatsumisago, Electrochim. Acta 149 (2014) 293.

31 S.M. Queiroz, J.C. Machado, A.O. Porto, G.G. Silva, Polymer, 42 (2001) 3095.

32 W.-J. Liang, P.-L. Kuo, J. Polymer Sci. Part A: Polymer Chem., 42 (2004) 151.

33 R.K. Gupta, H.Y. Jung, C.M. Whang, J. Mater. Chem., 12 (2002) 3779. 
34 M. Stefanescu, M. Stoia, O. Stefanescu, J. Sol-Gel Sci. Technol., 41 (2007) 71.

36 D. Fischer, D. Pospiech, U. Scheler, R. Navarro, M. Mesori, P. Fabbri, Macromol. Symp., 265 (2008) 134.

37 H.Y. Jung, R.K. Gupta, E.O. Oh, Y.H. Kim, C.M. Whang, J. Non-Cryst. Solids, 351 (2005) 372

38 P. Innocenzi, J.Non-Cryst. Solids, 316 (2003) 309.

39 M. Deepa, S.A. Agnihotry, D. Gupta, R. Chandra, Electrochim. Acta, 49 (2004) 373.

40 V. de Zea Bermudez, L. Alcácer, J.L. Acosta, E. Morales, Solid State Ion. 116 (1999) 197. 41 A. Bakker, S. Gejji, J. Lindgren, K. Hermansson, M.M. Probst, Polymer, 36 (1995) 4371. 42 J.F. Vélez, R.A. Procaccini, M. Aparicio, J. Mosa, Electrochim. Acta, 110 (2013) 200. 43 G. Nikolic, S. Zlatkovic, M. Cakic, S. Cakic, C. Lacnjevac, Z. Rajic, Sensors, 10 (2010) 684.

44 M. Marzantowicz, J.R. Dygas, F. Krok, A. Tomaszewska, G.Z. Zukowska, Z. Florjanczyk, E. Zygadło-Monikowska, Electrochim. Acta, 55 (2010) 5446.

45 M.R. Gizdavic-Nikolaidis, Z.D. Zujovic, N.R. Edmonds, C.J. Bolt, A.J. Easteal, J. NonCryst. Solids, 353 (2007) 1598.

46 J.M. Alía, H.G.M. Edwards, Vibrational Spectrosc. 24 (2000) 185.

47 W. Huang, R. French, P. Johansson, J. Lindgren, Electrochim. Acta, 40(13-14) (1995) 2147.

48 B. Riegel, S. Blittersdorf, W. Kiefer, S. Hofacker, M. Müller, G. Schottner, J. Non-Cryst. Solids, 226 (1998) 76.

49 M. Gnyba, M. Keränen, M. Kozanecki, R. Bogdanowicz, B.B. Kosmowski, P. Wroczynski, Optoelectronics Review, 10 (2002) 137.

50 S.K. Chaurasia, R.K. Singh, S. Chandra, Vibrational Spectroscopy, 68 (2013) 190.

51 F.E. Bailey, J.V. Koleske, Poly (ethylene Oxide), Academic Press, New York, 1976.

52W. Huang, R. Frech, Polymer, 35 (1994) 235.

53 M. Herstedt, M. Smirnov, P. Johansson, M. Chami, J. Grondin, L. Servant, J.C. Lassègues, J. Raman Spectros. 36 (2005) 762.

54 M.C. Borghini, M. Mastragostino, A. Zanelli, Electrochim. Acta, 41 (1996) 2369.

55 K. Nishio, K. Okubo, Y. Watanabe, T. Tsuchiya, J. Sol-Gel Sci. Technol., 19 (2000) 187.

56 W.-H. Hou, C.-Y. Chen, C.-C. Wang, Y.-H. Huang, Electrochim. Acta, 48 (2003) 679.

57 Y. Liu, J.Y. Lee, L. Hong, J.Power Sources 129 (2004) 303.

58 J. Xi, X. Ma, M. Cui, X. Huang, Z. Zheng, X. Tang, Chin. Sci. Bull. 49 (2004) 785.

59 M. Watanabe, A. Nishimoto, Solid State Ion. 79 (1995) 306.

60 J.B. Goodenough, Y. Kim, Chem. Mater., 22 (2010) 587.

61 S. Skaarup, K. West, B. Zachau-Christiansen, M. Popall, J. Kappel, J. Kron, G. Eichinger, G. Semrau, Electrochim. Acta 43 (1998) 1589.

62 P. Lobitz, H. Füllbier, A. Reiche, J.C. Illner, H. Reuter, S. Höring, Solid State Ion. 58 (1992) 41.

63 O.E. Geiculescu, R. Rajagopal, S.E. Creager, D.D. DesMarteau, X. Zhang, P. Fedkiw, J. Phys. Chem. B 110 (2006) 23130. 


\section{Table captions}

Table 1 Compositions of organic-inorganic hybrid electrolytes in the GTE system.

Table 2 FTIR assignments of the main absorption bands for sol-gel precursors and GTE hybrid network.

Table 3 FT-Raman assignments of the main absorption bands for GTE hybrid network.

Table 4 Ionic conductivity, activation energy and transference number for GTE solid hybrid electrolytes. 


\section{Figure captions}

Fig.1. Schematic representation of the synthesis and hybrid organic-inorganic structure developed after sol-gel reaction and organic polymerization.

Fig. 2. Scheme of the fabricated microbattery utilized for performed cycling performance.

Fig. 3. Photographs of hybrid a) self-supported samples prepared with PFTE molds and b) thin-films samples, both treated at $100^{\circ} \mathrm{C}$.

Fig 4. TGA curves of hybrid electrolytes without thermal treatment with different lithium content. b) DSC traces for the hybrid electrolytes with different GTED and Li content (LiTFSI).

Fig. 5.a) FTIR spectra of hybrid electrolytes GTE heat treated at $100{ }^{\circ} \mathrm{C}$ as a function of GTED contain. b) FTIR spectra of hybrid GTE solutions with different Li content. c) Crosslinking degree of GTE-2 composition $\left(50 \%\right.$ EGDE, $\left.\left[\mathrm{Li}^{+}\right] /[\mathrm{O}]=0.1\right)$ as a function of time during the organic network formation carried out at $60{ }^{\circ} \mathrm{C}$ ( band located at $912 \mathrm{~cm}^{-1}$ ).

Fig. 6.a) Raman spectra of hybrid electrolytes GTE heat treated at $100{ }^{\circ} \mathrm{C}$ as a function of GTED contain b) Raman spectra of hybrid electrolytes GTE heat treated at $100{ }^{\circ} \mathrm{C}$ with different Li content. c) Deconvolution of the peak corresponds to $\mathrm{CF}_{3}$ deformation mode in the Raman shift 790-770 $\mathrm{cm}^{-1}$.

Fig. 7. a) Ionic conductivity as function of temperature for GTE hybrid electrolytes for different GTED contains b) Ionic conductivity as function of temperature for GTE hybrid electrolytes with different $\mathrm{Li}$ content.

Fig. 8. Electrochemical stability window for LI/ GTE-2 hybrid solid electrolyte/ stainless.

Fig 9. Time-dependence response of $d c$ polarization for solid hybrid electrolyte of GTE-2 with a molar ratio of $\left[\mathrm{Li}^{+}\right] /[\mathrm{O}]=0.1$ and $50 \%$ EGDE Li metal $\mid$ GTE-2 $\mid \mathrm{Li}$ metal cell and impedance response of the same cell before and after the $d c$ polarization (inlet). Room temperature.

Fig 10. a) Representative galvanistatic discharge-charge profiles of a microcell prepared using lithium metal as anode, GTE-2 as solid electrolyte and $\mathrm{Li}_{4} \mathrm{Ti}_{5} \mathrm{O}_{12}$ films as cathode. b) Cycling performance of the same microcell. c) Variation in AC impedance spectra (before charge/discharge and after 500 cycles) of Li|GTE-2|Li cell. 
Table 1

\begin{tabular}{cccccc} 
& \multicolumn{5}{c}{ Composition (mol) } \\
\cline { 2 - 6 } & $\mathbf{G}^{a}$ & $\mathbf{E}^{b}$ & LiTFSI & {$\left[\mathbf{L i}^{+}\right] /[\mathbf{O}]$} & $\mathbf{G : E}^{c}$ \\
\hline GTE-1 & 1.0 & 0.7 & 0.23 & 0.10 & $60: 40$ \\
$\mathbf{G T E}-\mathbf{2}$ & 1.0 & 1.0 & 0.30 & 0.10 & $50: 50$ \\
$\mathbf{G T E}-\mathbf{3}$ & 1.0 & 1.5 & 0.40 & 0.10 & $40: 60$ \\
$\mathbf{G T E}-\mathbf{4}$ & 1.0 & 3.0 & 0.70 & 0.10 & $25: 75$ \\
$\mathbf{G T E}-\mathbf{5}$ & 1.0 & 1.0 & 0.00 & 0.00 & $50: 50$ \\
$\mathbf{G T E}-\mathbf{6}$ & 1.0 & 1.0 & 0.22 & 0.07 & $50: 50$ \\
$\mathbf{G T E}-\mathbf{7}$ & 1.0 & 1.0 & 0.60 & 0.20 & $50: 50$ \\
$\mathbf{G T E}-\mathbf{8}$ & 1.0 & 1.0 & 1.20 & 0.40 & $50: 50$
\end{tabular}

${ }^{\bar{a}} \mathrm{G}=$ GPTMS,${ }^{b} \mathrm{E}=$ EGDE, ${ }^{c} \mathrm{G}: \mathrm{E}=$ Molar ratio GPTMS:EGDE mol $\%$ 
Table 2

\begin{tabular}{|c|c|c|c|}
\hline \multicolumn{2}{|c|}{ Sol-gel Precursors } & \multicolumn{2}{|l|}{ GTE Hybrid } \\
\hline \multirow[t]{2}{*}{ GPTMS } & $\underline{\text { EGDE }}$ & Network & \multirow[b]{2}{*}{ Bond Assignments } \\
\hline & \multicolumn{2}{|c|}{ IR - Vibration frequency $\left(\mathrm{cm}^{-1}\right)$} & \\
\hline \multirow{6}{*}{ 3050-2995 } & $\sim 3500$ & $3600-3200$ & $v(\mathrm{O}-\mathrm{H})$ \\
\hline & $\sim 3060$ & & $v(\mathrm{C}-\mathrm{H})$ \\
\hline & & 2979-2974 & $v_{\mathrm{as}} \mathrm{CH}_{3}\left(\mathrm{OC}_{2} \mathrm{H}_{5}\right)$ \\
\hline & & 2932-2928 & $v_{\mathrm{as}} \mathrm{CH}_{2}\left(\mathrm{OC}_{2} \mathrm{H}_{5}\right)$ \\
\hline & $\sim 2880$ & $2883-2880$ & $v_{\mathrm{s}} \mathrm{CH}_{3} / \mathrm{v}_{\mathrm{s}} \mathrm{CH}_{2}\left(\mathrm{OC}_{2} \mathrm{H}_{5}\right)$ \\
\hline & & $1645^{*}$ & $v(\mathrm{C}=\mathrm{C})(\mathrm{CH}=\mathrm{CH}$ from $n-\mathrm{MI})$ \\
\hline \multirow[t]{2}{*}{$1480-1370$} & & $1480-1370$ & $\delta \mathrm{CH}_{3}$ from GPTMS \\
\hline & $1462-1456$ & 1454 & $\delta_{\mathrm{as}} \mathrm{HCH} / \mathrm{CH}_{2}$ scissor / $\delta\left(\mathrm{CH}_{2}\right)$ \\
\hline \multirow[t]{4}{*}{1420} & & $1410-1414^{b r}$ & $\delta \mathrm{CH}_{2} / v_{\mathrm{as}}(\mathrm{C}-\mathrm{O}-\mathrm{O})$ \\
\hline & & 1353 & $\mathrm{CH}_{2}$ wagg. $/ v_{\mathrm{as}}\left(\mathrm{SO}_{2}\right)$ from LiTFSI \\
\hline & & 1332 & $v_{\text {as }}\left(\mathrm{SO}_{2}\right)$ from LiTFSI \\
\hline & & 1273-1294* & $v(\mathrm{C}-\mathrm{Si}-\mathrm{O})$ \\
\hline $1254 *$ & 1253 & $1253^{\text {sh }}$ & $\delta\left(\mathrm{Si}-\mathrm{CH}_{2}\right)$ \\
\hline \multirow[t]{9}{*}{$1260-1240$} & $1250 ; 909-907$ & & $\delta$ epoxide (breathing ring deformation) \\
\hline & & 1228 & $v_{\mathrm{s}} \mathrm{CF}_{3}$ from LITFSI \\
\hline & & 1194-1189 & $v_{\mathrm{as}}(\mathrm{Si}-\mathrm{O}-\mathrm{Si})_{\mathrm{LO}}$ \\
\hline & & $1138-1134^{s h}$ & $\begin{array}{l}v(-\mathrm{Si}-\mathrm{O}-\mathrm{Si}-\mathrm{O}-) \text { (crosslinking) / } \\
v_{\mathrm{s}}\left(\mathrm{SO}_{2}\right) \text { from LiTFSI }\end{array}$ \\
\hline & 1093 & 1094-1082 & $v_{\mathrm{as}}(\mathrm{Si}-\mathrm{O}) / v_{\mathrm{as}}(\mathrm{C}-\mathrm{O}) / v_{\mathrm{as}} \mathrm{CF}_{3}$ from LiTFSI \\
\hline & & $1054-1040$ & $v_{\mathrm{s}}(\mathrm{C}-\mathrm{O}-\mathrm{C}) / v_{\mathrm{as}}(\mathrm{Si}-\mathrm{O}-\mathrm{Si})$ \\
\hline & 993-989 & & $v(\mathrm{C}-\mathrm{O}-\mathrm{C})$ \\
\hline & & $956^{s h}$ & $v(\mathrm{Si}-\mathrm{OH})$ \\
\hline & & 953-940 & $v_{\mathrm{s}}(\mathrm{C}-\mathrm{O}) / v(\mathrm{C}-\mathrm{C}) / v_{\mathrm{s}}(\mathrm{Si}-\mathrm{O})$ \\
\hline \multirow[t]{5}{*}{912} & & & $v_{\mathrm{s}}$ epoxide \\
\hline & & 907 & $v(\mathrm{C}-\mathrm{OH}) / \delta(\mathrm{Si}-\mathrm{O}-\mathrm{Si})$ \\
\hline & & $884-880$ & $\delta \mathrm{CH}_{2} / v(\mathrm{C}-\mathrm{OH})$ \\
\hline & & $854-852$ & $\delta(\mathrm{Si}-\mathrm{O})$ \\
\hline & & 845 & $v(-\mathrm{Si}-\mathrm{O}-\mathrm{Si}-)($ crosslinking $)$ \\
\hline \multirow[t]{3}{*}{816} & & & $v\left(\mathrm{Si}-\mathrm{O}-\mathrm{CH}_{3}\right)$ \\
\hline & & $795-787$ & $v_{\mathrm{s}}(\mathrm{Si}-\mathrm{O}-\mathrm{Si})$ \\
\hline & & $763-760 *$ & $v(\mathrm{~S}-\mathrm{N})$ from LiTFSI \\
\hline \multirow[t]{4}{*}{750} & & & $\delta\left(\mathrm{Si}-\mathrm{O}-\mathrm{CH}_{3}\right)$ \\
\hline & & 740 & $v_{\mathrm{s}}(\mathrm{S}-\mathrm{N}-\mathrm{S})$ from LiTFSI \\
\hline & & 695 & $v(\mathrm{O}-\mathrm{Si}-\mathrm{O}) / \delta(\mathrm{Si}-\mathrm{C})$ \\
\hline & & $656-652$ & $\delta(\mathrm{SNS})$ from LiTFSI \\
\hline
\end{tabular}

The notations: sh, br and asterisk correspond to shoulder, broad and overlap peaks, respectively. 
Table 3

\begin{tabular}{|c|c|}
\hline $\begin{array}{l}\text { Raman Shift } \\
\left(\mathbf{c m}^{-1}\right)\end{array}$ & Assignments \\
\hline 1494 & $\delta \mathrm{CH}_{2} / \delta \mathrm{CH}_{3}$ \\
\hline 1468 & $\mathrm{CH}_{2}$ scissor \\
\hline 1253 & $v_{\mathrm{s}} \mathrm{CF}_{3}$ from LiTFSI $/ v \mathrm{CH}_{2}$ \\
\hline 1149 & $\begin{array}{l}v_{\text {as }}(\mathrm{Si}-\mathrm{O}-\mathrm{Si})_{\mathrm{To}} / \mathrm{C}-\mathrm{C} / \mathrm{C}-\mathrm{O} \\
\text { overlapped with } v_{\mathrm{s}} \mathrm{SO}_{2} \mathrm{de} \\
\text { LiTFSI }\end{array}$ \\
\hline 1144 & $\begin{array}{l}v(-\mathrm{Si}-\mathrm{O}-\mathrm{Si}-\mathrm{O}-) \text { (crosslinking) } \\
\text { Coupled } v(\mathrm{C}-\mathrm{O}) / v(\mathrm{C}-\mathrm{O}-\mathrm{C})\end{array}$ \\
\hline $1132^{s h}$ & $v_{\mathrm{s}}(\mathrm{C}-\mathrm{O})_{\text {trans }}, \mathrm{CH}_{2}, \mathrm{v}_{\mathrm{s}} \mathrm{SO}_{2}$ \\
\hline $\begin{array}{c}1122^{s h} \\
1034\end{array}$ & $\begin{array}{l}\text { Coupled } v(\mathrm{C}-\mathrm{C}) / \mathrm{CH}_{2} \text { wagg. } \\
v(\mathrm{~S}-\mathrm{O}) \text { free anion TFSI }\end{array}$ \\
\hline $898-850$ & $\delta \mathrm{CH}_{2}, v(\mathrm{C}-\mathrm{O})$ \\
\hline 857 & $\begin{array}{l}\mathrm{Li}^{+}--\mathrm{O} \text { (ether oxygens) } \\
\text { complexes } \\
v(-\mathrm{Si}-\mathrm{O}-\mathrm{Si}-) \text { (crosslinking) }\end{array}$ \\
\hline 776 & $\delta_{\mathrm{s}} \mathrm{CF}_{3}$ from LiTFSI \\
\hline 748 & $v_{\mathrm{s}}(\mathrm{S}-\mathrm{N}-\mathrm{S})$ from LiTFSI \\
\hline 586-582 & $\mathrm{Si}^{*}(\mathrm{OR})_{3} \mathrm{OSi}(\mathrm{OR})_{3}$ (oligomers) \\
\hline 563 & $\mathrm{Si}^{*}(\mathrm{OR})_{3} \mathrm{OSi}(\mathrm{OR})_{2} /-\mathrm{OSi}^{*}(\mathrm{OR})_{3}$ \\
\hline$\sim 410$ & $v(\mathrm{Si}-\mathrm{O}-\mathrm{Si})$, inorganic network \\
\hline 323 & $\mathrm{SO}_{2}$ wagg. from LiTFSI \\
\hline 286 & $\mathrm{CF}_{3}$ wagg. from LiTFSI \\
\hline
\end{tabular}

sh correspond to shoulder. 
Table 4

Table 4

\begin{tabular}{cccc}
\hline Composition & $\begin{array}{c}\boldsymbol{\sigma}_{25^{\circ} \mathbf{C}} \\
(\mathbf{S} / \mathbf{c m})\end{array}$ & $\begin{array}{c}\boldsymbol{E}_{\boldsymbol{a}} \\
(\mathbf{e V})\end{array}$ & $\begin{array}{c}\boldsymbol{t}_{\boldsymbol{L} \boldsymbol{i +}} \\
\left(\mathbf{2 5}^{\mathbf{}} \mathbf{C}\right)\end{array}$ \\
\hline $\mathrm{GTE}-1$ & $1.2 \times 10^{-6}$ & 0.64 & 0.16 \\
$\mathrm{GTE}-2$ & $1.1 \times 10^{-5}$ & 0.56 & 0.37 \\
$\mathrm{GTE}-3$ & $2.6 \times 10^{-5}$ & 0.49 & 0.25 \\
$\mathrm{GTE}-6$ & $2.4 \times 10^{-6}$ & 0.60 & 0.05 \\
$\mathrm{GTE}-7$ & $5.8 \times 10^{-6}$ & 0.59 & 0.27 \\
\hline
\end{tabular}

$\sigma$ : conductivity

$E_{a}$ : activation energy

$t_{L i+}: \mathrm{Li}^{+}$transference number 
Figure 1
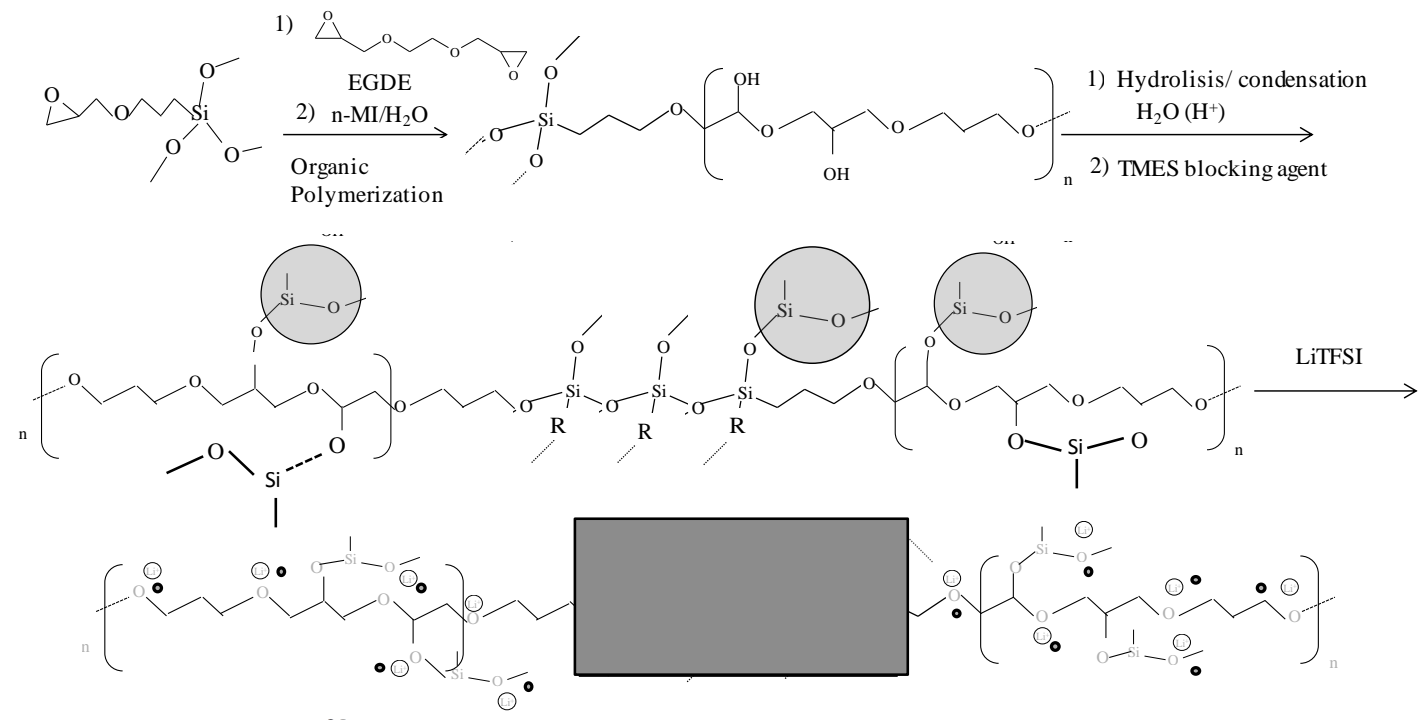

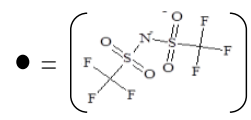

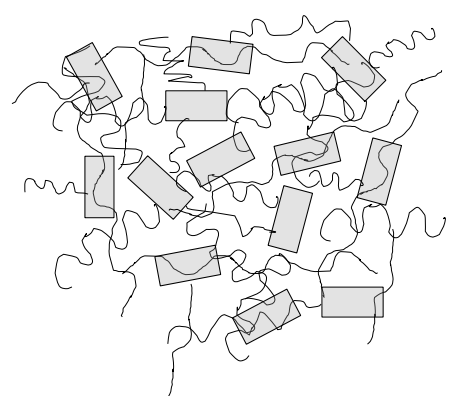


Figure 2

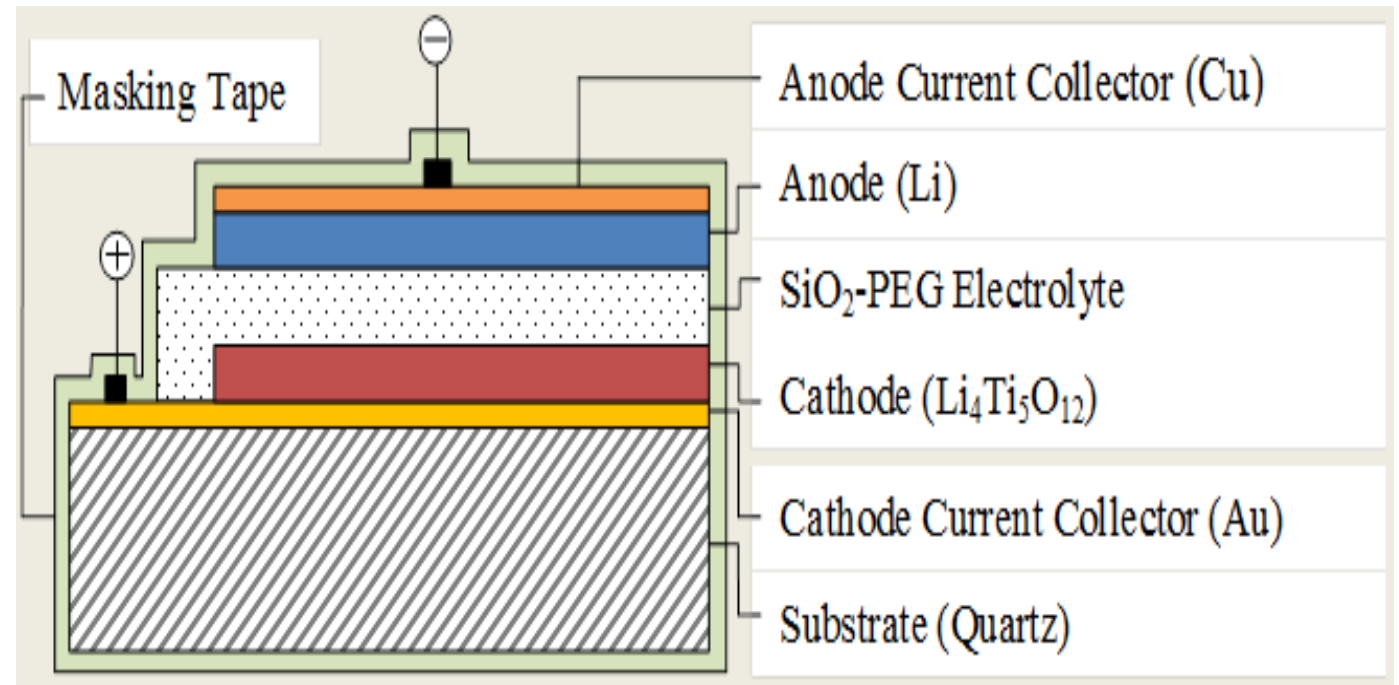


Figure 3

Figure 3

(a)

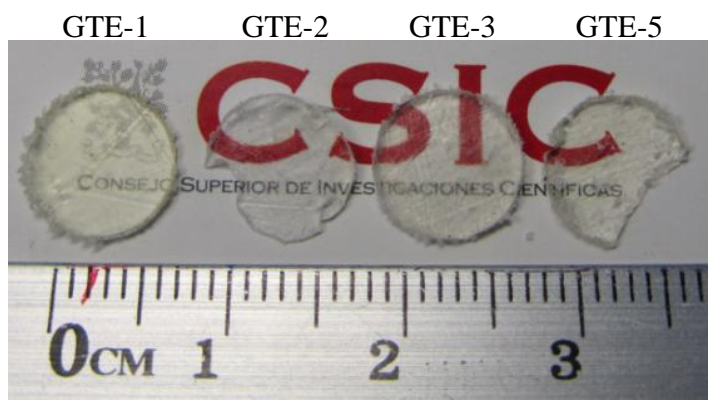

(b)

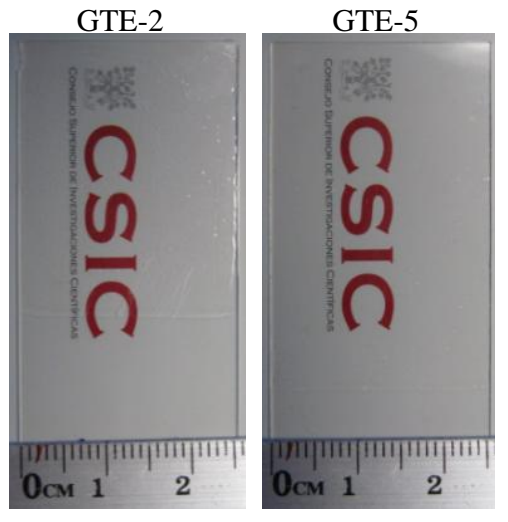


a)

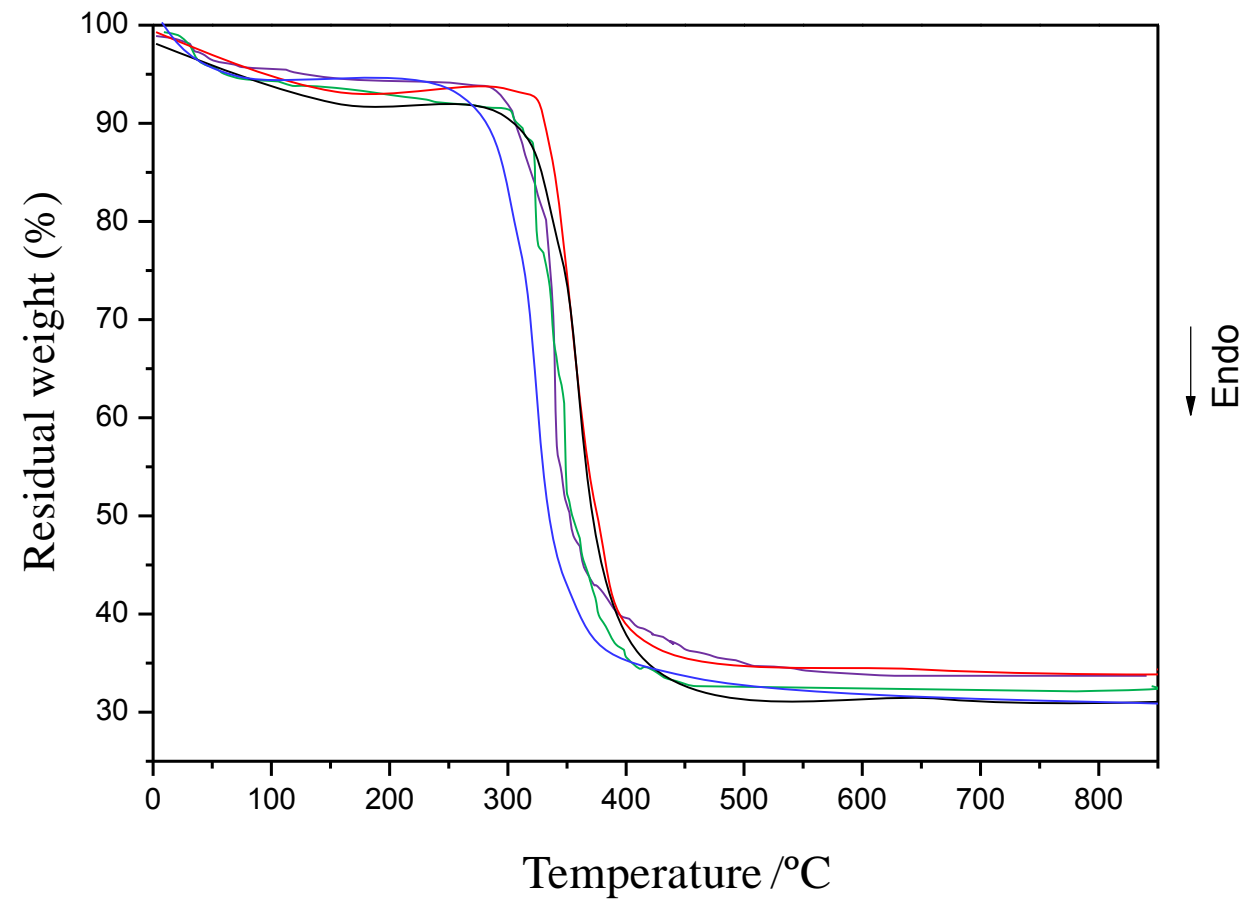

b)

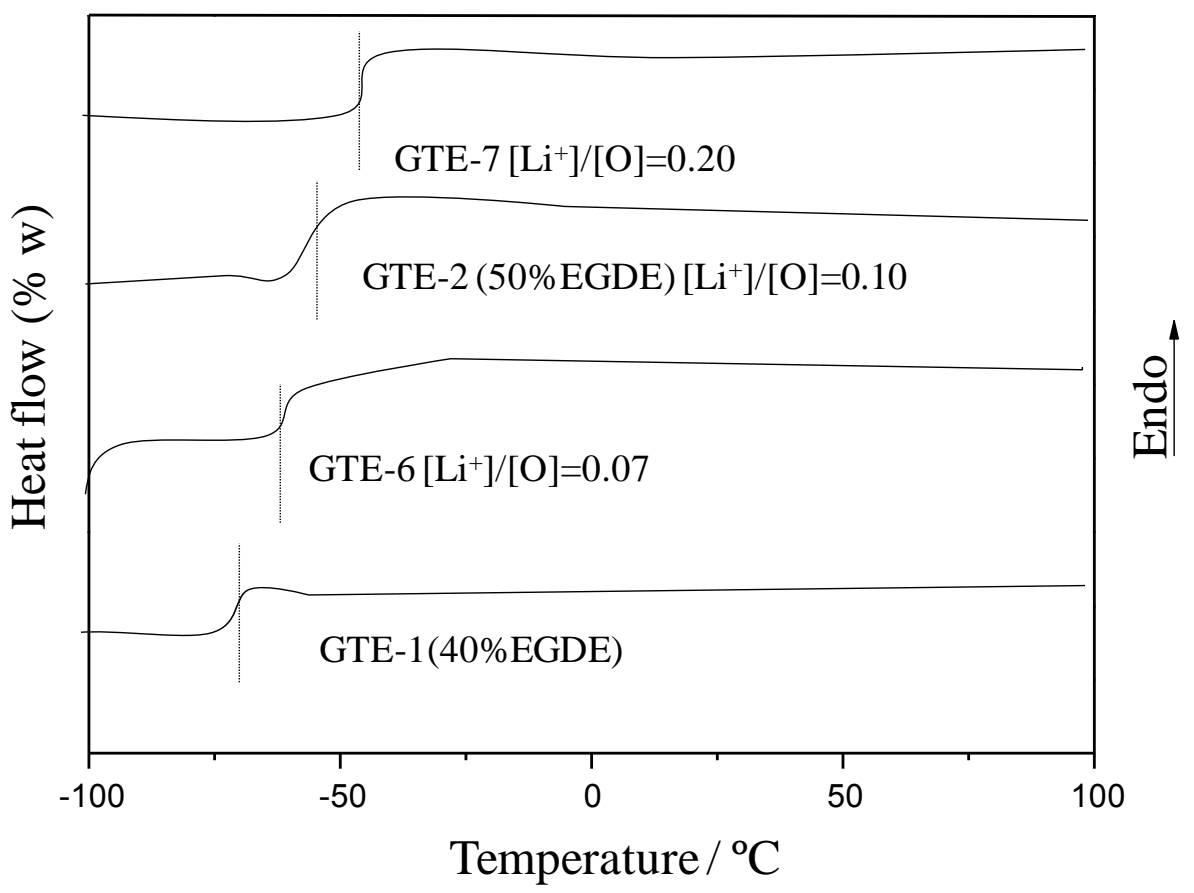


Figure 5

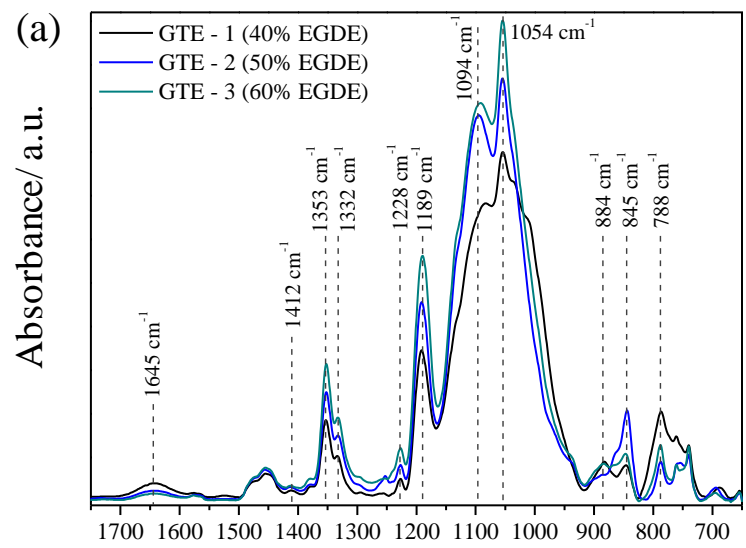

Wavenumber $/ \mathrm{cm}^{-1}$

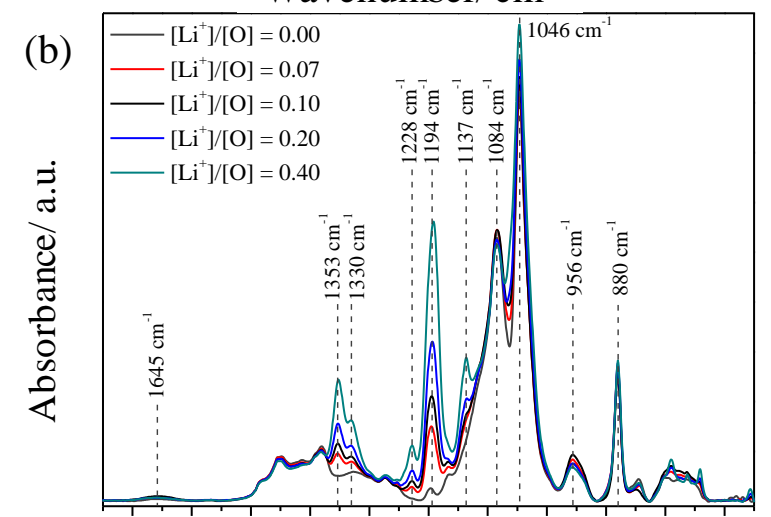

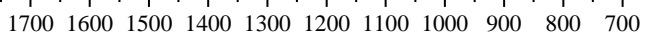

Wavenumber/ $\mathrm{cm}^{-1}$

(c)

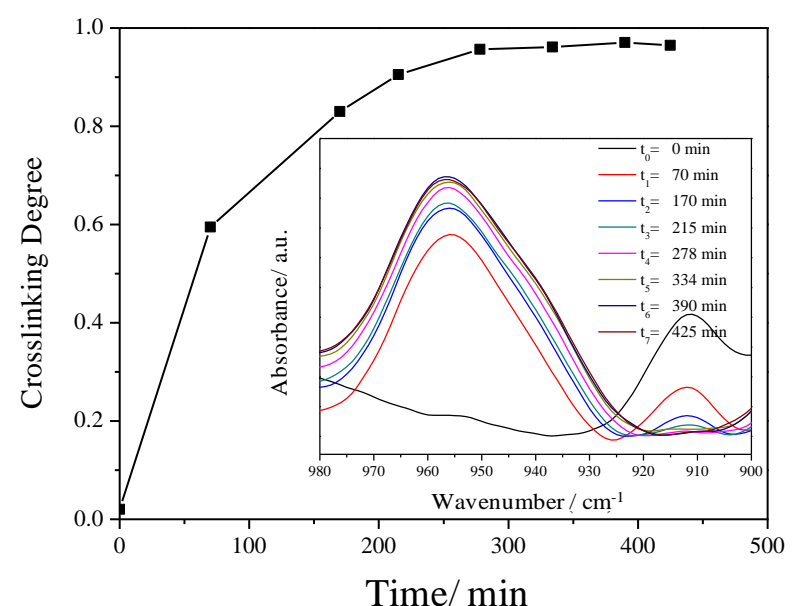

Time/ min 

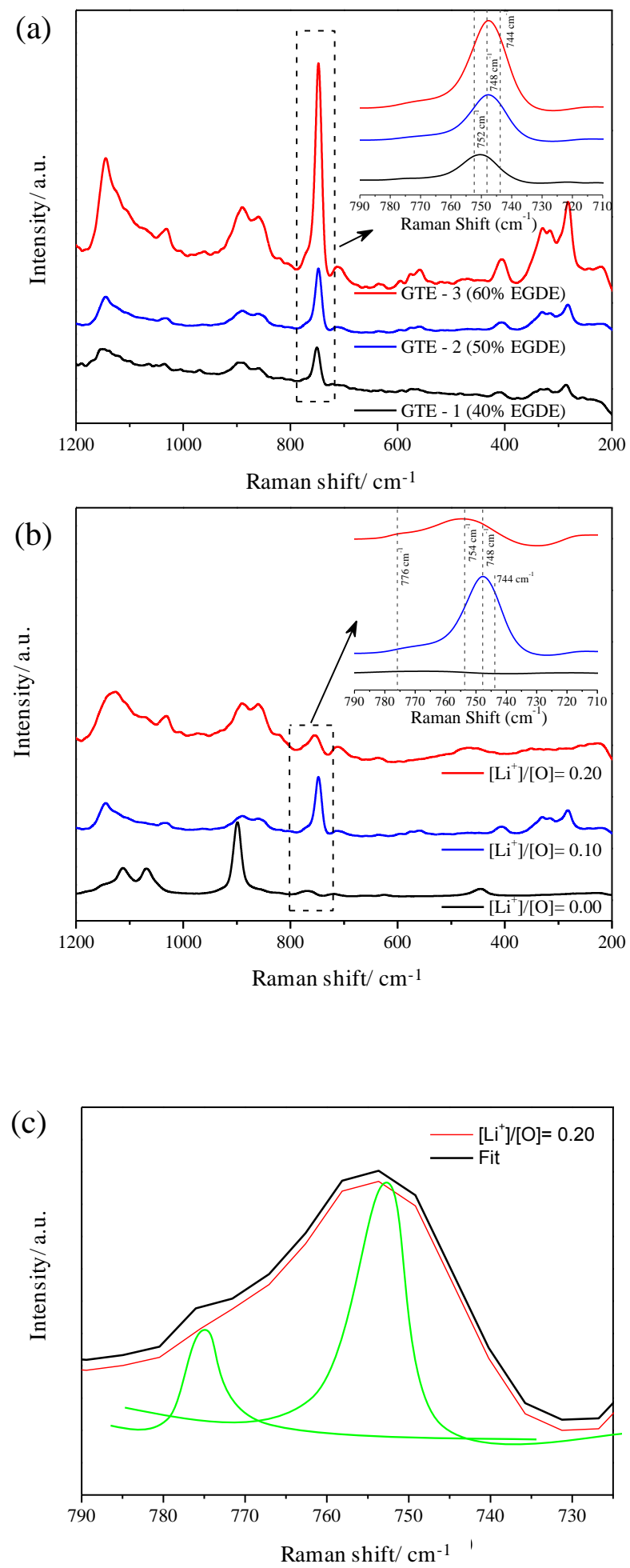
Figure 7

(a)

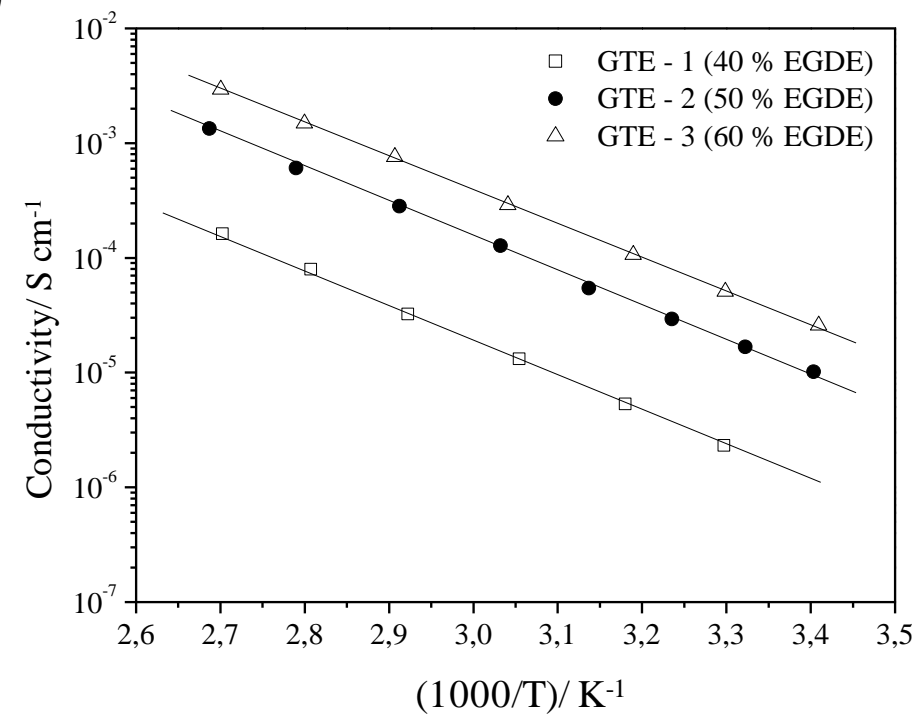

(b)

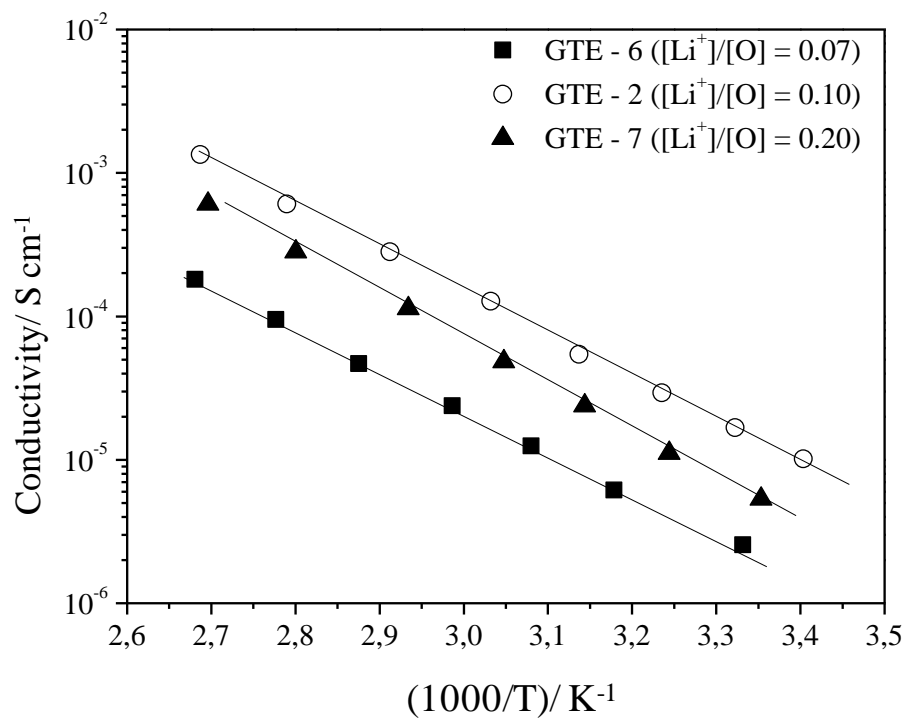


Figure 8

Figure 8

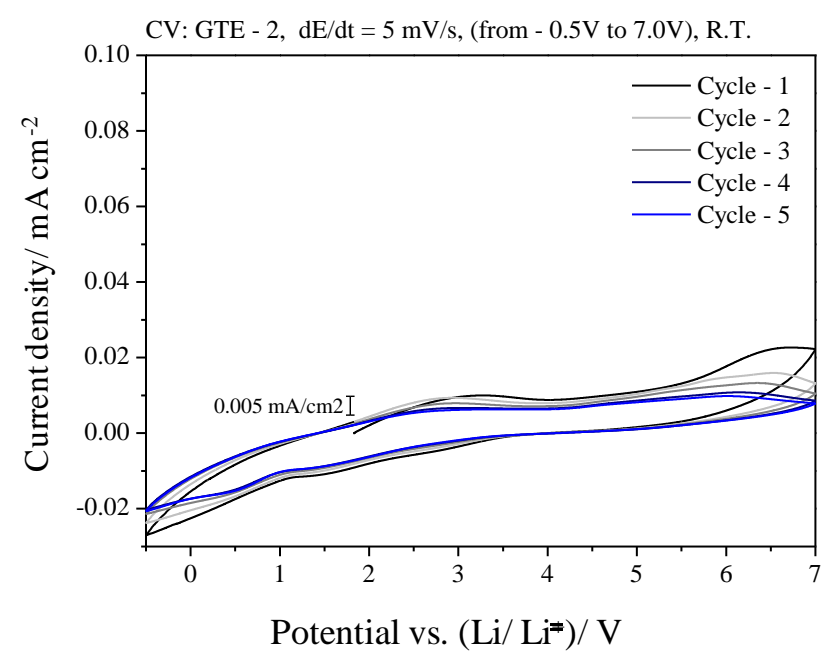


Figure 9

Figure 9

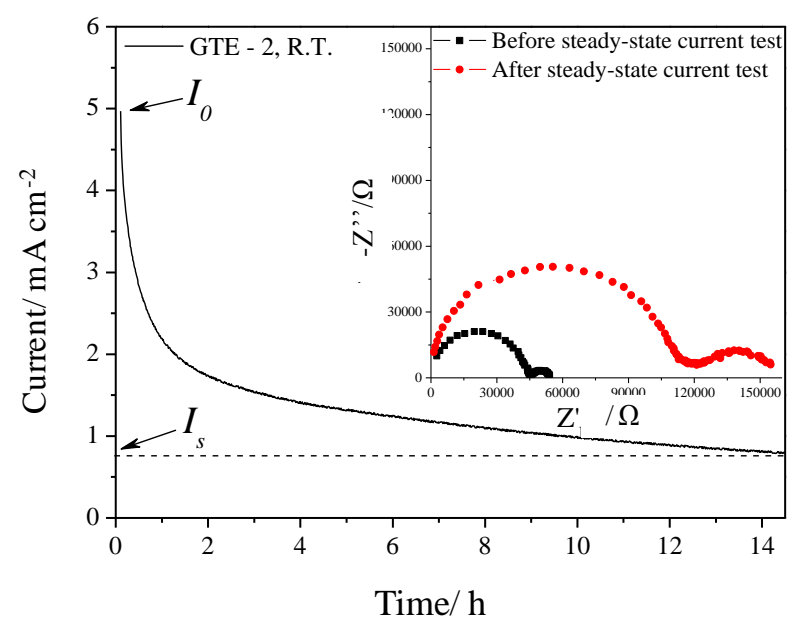


Figure 10

a)

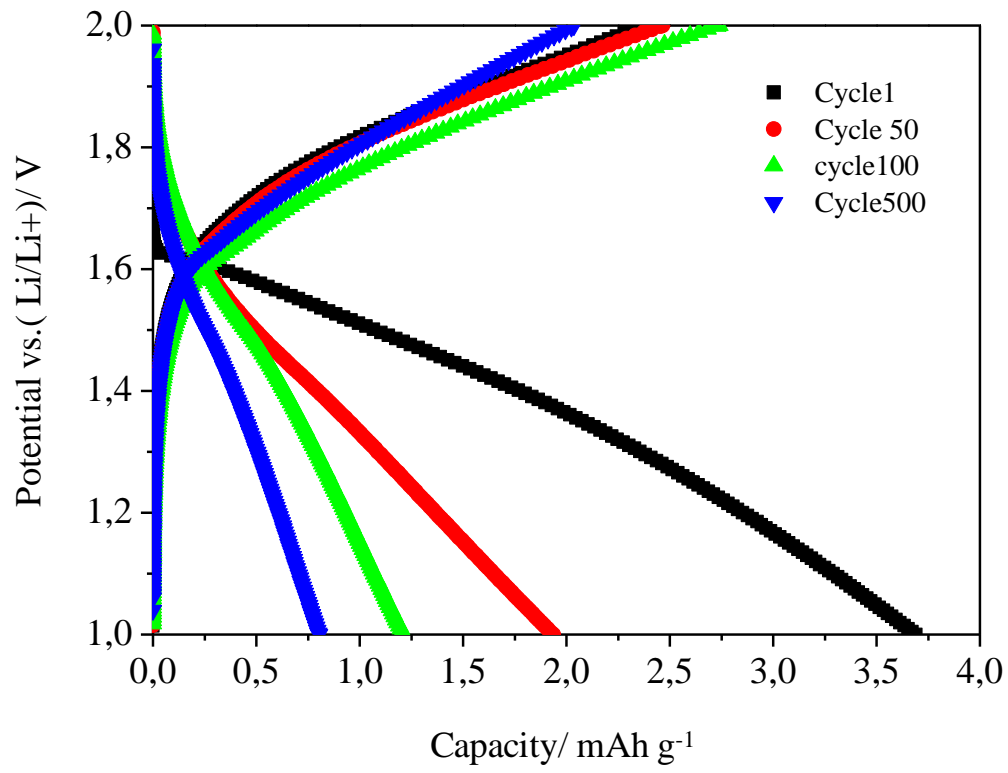

b)

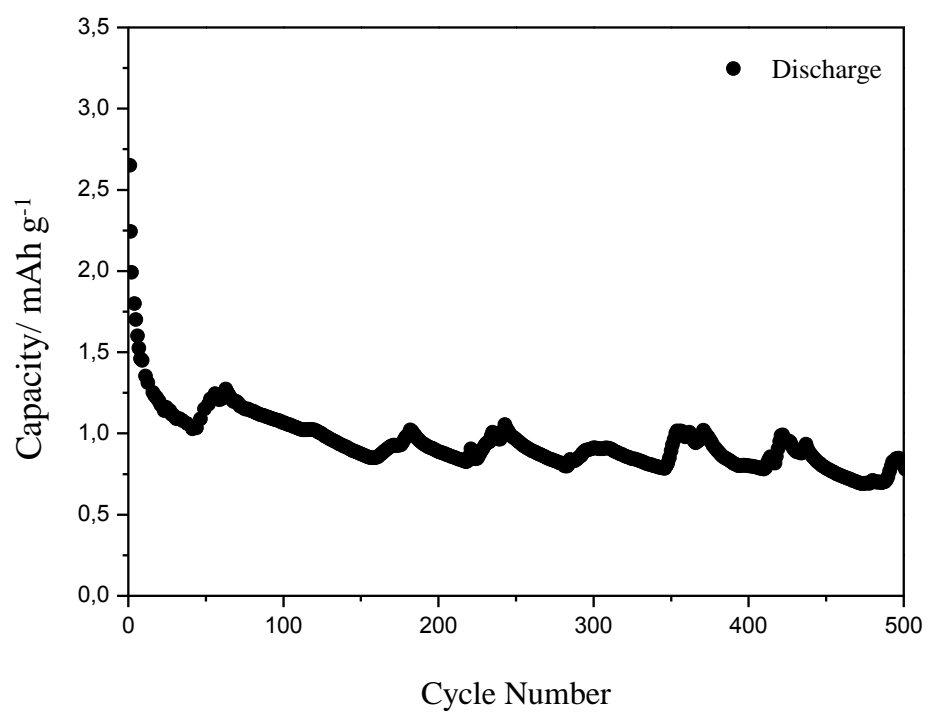

c)

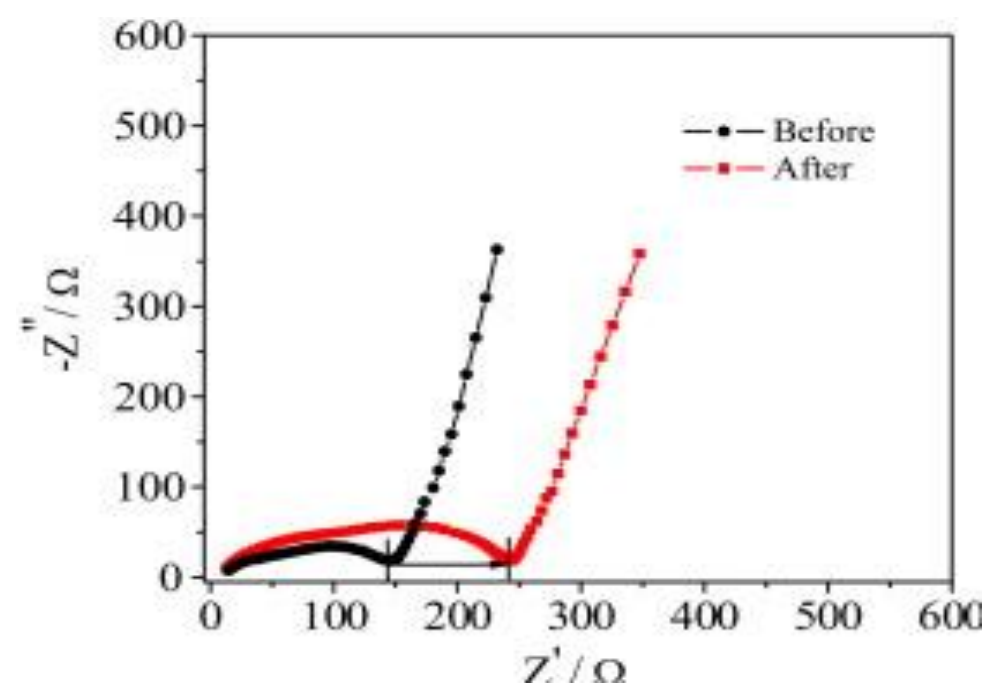

